\author{
AMISOS / AMISOS \\ Cilt/Volume 6, Say1/Issue 11 (Aralık/December 2021), ss./pp. 267-284 \\ ISSN: 2587-2222 / e-ISSN: 2587-2230 \\ DOI: $10.48122 /$ amisos. 987156
}

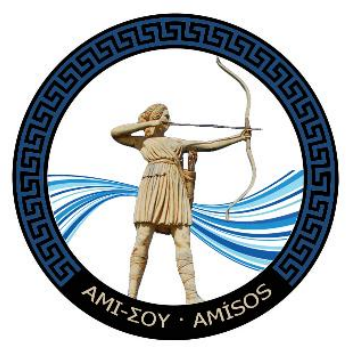

Özgün Makale / Original Article

\title{
SON DÖNEM ÇALIŞMALARI IŞIĞINDA ANAMUR MAMURE KALESİ
}

\section{ANAMUR MAMURE CASTLE IN THE LIGHT OF LAST PERIOD WORK}

\author{
Suat ŞAHİN - Sinan ÖZCAN - Süleyman Ali SOL ${ }^{*}$
}

\section{$\ddot{O} \mathbf{z}$}

Mersin-Antalya karayolu üzerinde, Anamur'un $6 \mathrm{~km}$. güneydoğusunda, deniz kenarında yer alan Mamure Kalesi'nin oturum alanı $23.500 \mathrm{~m}^{2}$ dir. Mamure Kalesinin pek çok Anadolu kalesi gibi antik temeller üzerine inşa edildiği ve kalenin bulunduğu yerde MS 3.- 4. yüzyıllarda bir Roma yerleşimi olduğu iddia edilmektedir. Bu antik kentin adı "Rygmonia" olarak adlandırılmıştır. M.S IV. Yüzyılda Romalılar tarafından yapılmış olan kale, sonraları Bizans Dönemi’nde genişletilmiştir. Selçuklu Sultanı Alaaddin Keykubat tarafından 1221 yılında ele geçirildiği sırada yıkılan kalenin yerine bugünkü kale yapılmıştır. Bu alanda da kale içerisinde 1 adet camii ve kale dışında 1 adet hamam yapısı mevcuttur. Daha sonra burası; Karamanoğulları ve Osmanlılara geçmiştir. Bir kervansaray görünümünde olan Mamure Kalesi, en iyi korunmuş Anadolu kalelerinden biridir. Kuleler, surlar ve mazgalları ile hala ayaktadır. 2020-2021 yılı çalışmalarında Mamure Kalesi Restorasyon faaliyetleri kapsamında Anamur Müze Müdürlüğü'nce Kale içerisinde C ve B avlularında bilimsel kazılar gerçekleştirilmiştir. Son dönem kazı çalışmalarında tespit edilen buluntu ve kalıntılara yönelik değerlendirme bu makalenin konusunu oluşturmaktadır.

Anahtar Kelimeler: Anamur, Mamure Kalesi, Dağlık Kilikya, Kazı, Ortaçağ, Seramik.

\footnotetext{
* Anamur Müze Müdürlüğü, Mersin/Türkiye. E-posta: suatsahin2301@gmail.com ORCID ID: https://orcid.org/0000-0002-6182-2345

Anturia Arkeoloji ve Sosyal Çevre Etiği Okulu, Çavdarhisar/Kütahya/Türkiye. E-posta: sinanozcan6@gmail.com ORCID ID: https://orcid.org/0000-0001-6480-9907

Anamur Müze Müdürlüğ̈̈, Mersin/Türkiye. E-posta: alisol3307@ gmail.com ORCID ID: https://orcid.org/0000$\underline{0002-4066-0172}$
} 


\begin{abstract}
On the Mersin-Antalya highway, $6 \mathrm{~km}$ from Anamur. The residence of Mamure Castle, located in the southeast by the sea, is $23.500 \mathrm{~m}^{2}$. It is claimed that Mamure Castle, like many Anatolian castles, was built on ancient foundations and that the castle was a Roman settlement in the 3rd to 4th centuries. The name of this ancient city was named as "Rygmonia". M.S IV. The castle, which was built by the Romans in the century, was expanded later by the Byzantines and the Crusaders. The castle was built instead of the castle that was destroyed when it was captured by the Seljuk Sultan Alaaddin Keykubat in 1221. Then here; It passed to the Karamanids and Ottomans. Mamure Castle, which looks like a caravanserai, is one of the best preserved Anatolian cities. It is still standing with its towers, ramparts and battlements. Scientific excavations were carried out in the courtyards C and B by the Anamur Museum Directorate within the scope of the Mamure Castle Restoration activities in 2020-2021. Finds and remains determined from these excavations will be examined in the text.
\end{abstract}

Keywords: Anamur, Mamure Castle, Mountainous Cilicia, Excavation, Medieval Age, Ceramic.

\title{
Giriş
}

Mamure Kalesi, Mersin-Antalya karayolu üzerinde, Anamur'un $6 \mathrm{~km}$. güneydoğusunda, deniz kenarında yer almaktadır. UNESCO Dünya Mirası Merkezi, 2012 Yılında Mamure Kalesi'ni Dünya Mirası geçici listesine almıştır. İç kale ve dış kale olmak üzere 2 bölümden oluşan ${ }^{1}$ Mamure Kalesi, ilk olarak MS 3. yy.'da Roma Dönemi'nde inşa edilmiş, MS 395 yılında Bizans İmparatorluğu'nun, MS 8. yüzyıldan sonra ise Araplar ile Bizanslılar arasında el değiştirmiştir. ${ }^{2}$ I.Alâeddin Keykubad (1190-1237) döneminde ise iç kale onartılmış ve MS 1230 'den sonra Karamanoğullarının atalarının girmiştir. Kalenin kitabesine göre Karamanoğlu Sultan İbrahim tarafından Hicri 850 - Miladi 1450 yılında iç kale büyük bir tamir görmüştür. Bu tarihten sonra kaleye, mamur edilen manasında "Mamure Kalesi" denilmiştir. ${ }^{3}$

Evliya Çelebi, Mamure Kalesi başlığı altında şu paragrafı yazmıştır:

"Bu kale eskiden Venedikliler elinde büyük bir kale imiş. II. Sultan Selim zamanında burasını Lala Mustafa Paşa fethetmiş ve kaleyi tamir ettirmiştir. Sağlam bir kaledir. Bu Kale Silifke kazasında Paşa Hassı ve Voyvodalı̆̆ıdır. Otuz Köyü vardır. Buranın Yeniçeri Serdan ve 150 neferi vardır ve Kıbrıs'ın iskelesidir. Bu havali halkı buraya Anamur İskelesi derler. Kibrıs'a 40 mildir. Camisi, hanı, hamamı vardır. Halk çok zaman yaylada oturur, çünkü havast pek ăgırdır."

Osmanlı Dönemi'nde 16. ve 18. Yüzyıllarda kale iki kez tamir edilmiştir. Vakıflar Genel Müdürlüğü tarafından da 1966-1967 ve 1970-1973 yıllarında restorasyonu yapılmıştır. ${ }^{5}$

\footnotetext{
${ }^{1}$ Boran'a göre Mamure Kalesi, iç kale ve dış kaleden oluşmaktadır. İç kale; surlarla çevrili bir kentin en yüksek yerinde hükümdarın, beyin ya da komutanın oturmasına ayrılmış, en son savunma yeri olan kale bölümüne denir. Surlarla çevrili iç kalede, yönetici sarayı, beylerin konutları, darphane, tutukevi ve ibadethane (cami, kilise) gibi yapılar yer almaktadır. Kentin asıl bölümünü oluşturan şehristan (şehir), ticaret ve konut alanlarını, dini ve diğer kamu yapılarını içine alan bölüme denmektedir. Bilgi için bkz: URL 1.

${ }^{2}$ Boran 2004, 214.

${ }^{3}$ Boran 2004, 215.

${ }^{4}$ Evliya Çelebi Seyahatname'den aktaran: Karamanoğlu 2012, 138.

${ }^{5}$ Erdoğan 1968, 153.
} 


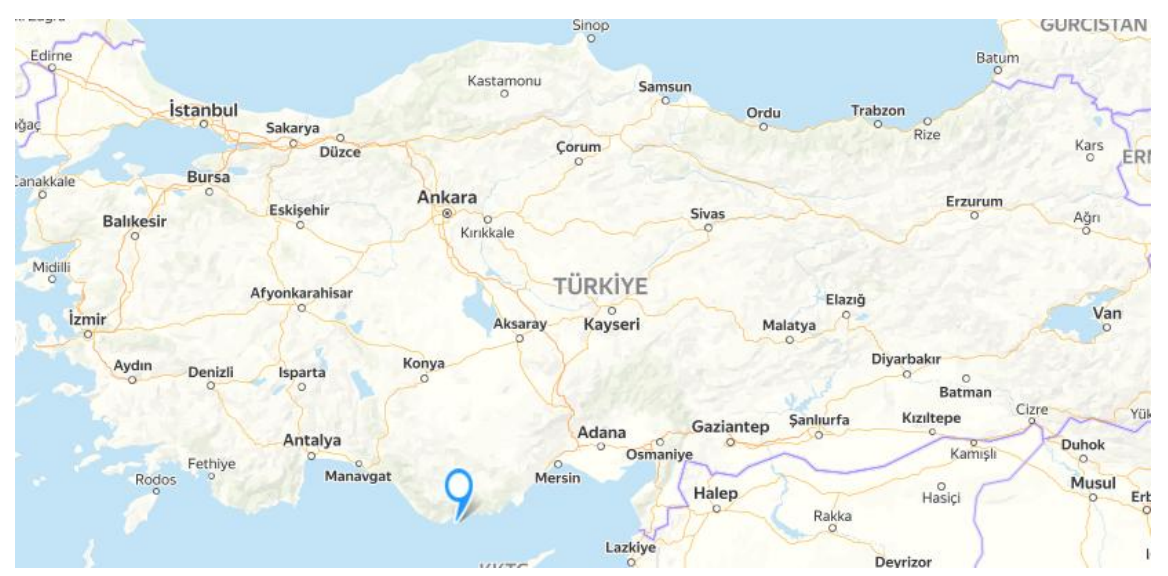

Res. 1: Mavi ile İşaretli Anamur Mamure Kalesi Konumu (Kaynak: URL 2 )

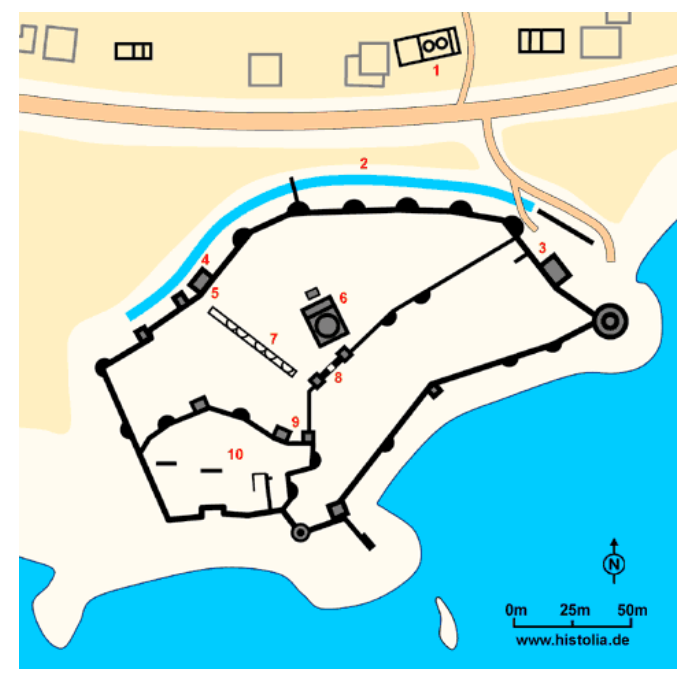

Res. 2: Mamure Kalesi Planı (Kaynak: URL 3)

\section{a. Coğrafi Konum ve Mimari Tanım}

İç kale, Anamur şehrinin içinde ve denizin kenarında, dış kale ise Mersin-Antalya karayolunun yanındadır. Kale yüksek duvarlarla ayrılmış, en güneyinde C ve A Avlusu, onların kuzeyinde B avlusu ile İç Kale Camisi olmak üzere 3 avludan oluşmaktadır. Anamur Mamure Kalesi, deniz kenarındaki kayalıklardan ve sahil düzlügünden yararlanılarak yapıldığı için düzgün bir plân göstermez.

Dış kalenin surlarından günümüze hiçbir şey kalmamasına karşılık iç kale sağlamdır. Kalenin batısında köprü ile geçilen su dolu bir hendek ile iki tane giriş kapısı yer almaktadır. $\mathrm{Bu}$ yöndeki surlar burçlarla desteklenmiş olmasına rağmen düzgün bir plâna sahip değildir. Giriş kapılarından ikincisi batı surlarının kuzeye yakın yerinde açılmışsa da günümüzde kullanılmamaktadır. Mamure Kalesi'nin iç kale bölümü birbirine geçmeli üç bölümden oluşmaktadır. Bu bölümler muhtemelen denizden gelen saldırıya karşı tahkim edilmiştir. İç kalenin surları seyirdimler ve mazgallar ile çok sağlam bir savunmaya sahiptir. Surların beden duvarlarındaki merdivenler sivri kemerli nişleriyle diğer Türk kalelerinin özelliklerini tekrarlamaktadır. Kalenin surlarında farklı dönemlerdeki tamirlerin izlerine rastlamak mümkündür. Özellikle Karamanoğlu ve Osmanlı dönemi tamirleri açıç̧a görülmektedir. ${ }^{6}$ Kalede düzgün kesme ve moloz taş birlikte kullanılmıştır. Giriş kapısının yanındaki küçük

\footnotetext{
${ }^{6}$ Boran 2004, 215.
} 
kapıdan baş kuleye çıkılmaktadır. Giriş içindeki yoldan batıdaki kulenin içine, ikincisi de kale kapısının bulunduğu dört köşe burcun birinci katına gitmektedir. Baş kule ile cümle kapısının bulunduğu kule, savunma sisteminin en önemli iki öğesidir. Baş kulenin birinci, ikinci ve üçüncü katlarından başlayarak kalenin bütün surları üzerinde dolaşan bir yol ağı vardır. Deniz kenarındaki surlar kuzeydoğu-güneydoğu doğrultudadır. Kuzeydoğu baş kuleden başka dairevi ve dört köşe altı burçla deniz tarafi korunmuştur.

\section{b. Mamure Kalesi 1988 Yılı Çalışmalarına Dair}

Kalede ilk olarak Anamur Müze Müdürlüğü'nce 1988 yılında kurtarma kazısı çalışmaları yapılmıştır. Bu çalışmaların sonunda ${ }^{7}$ zikzak şeklindeki dış kale surları ortaya çıkarılmıştır. Roma Dönemi ev temelleri, kule çevresinde de başka antik yıkıntılar ve kalenin dışında yer alan düzlükte hamam yapısı ortaya çıkarılmıştır. ${ }^{8}$

Mamure Kalesi'nin kuzeyinde bulunan hamam, Anamur'dan Bozyazi'ya karayolu üzerinde Mamure Kalesi'nin kuzeyinde yer almaktadır. Hamamın giriş alanı tahrip edilmiş, ancak soğukluk ve sicaklık yerleri hala iyi korunmuştur. Küçük bina mimari açıdan Türk hamamının güzel bir örneğidir. ${ }^{9}$ Duvarlar, Horasan harc1 ile birbirine tutturulmuş, yer yer ahşap hatıllarla güçlendirilmiş kaba taş dizilerinden yapılmıştır. Güney cephesinin ortasındaki bir kapı hamamın soyunma odasına açılır. Batı cephesinin duvarı, güney duvarı ile soğukluk duvarına birleştiği köşeden yıkılmıştır. Soğukluk yerinin kuzeyindeki üçüncü kapı sıcaklık yerine açılır. Sıcaklık yerinin karşısındaki nişlerin her iki yanındaki simetrik olarak yapılan kapılar hamamın dinlenme odalarına açılır. Bina zamanla hasar gördüğü için onarımlar sırasında duvarlar yenilenmiştir. Sonuç olarak, orijinal kalem işi duvar süslemelerinin çok az örneği günümüze kadar gelmiştir. Bugün hala görülebilen kalem işi süslemeler, sıcaklık yerindeki duvarlarında çok iyi korunmuş olanlardır. Tüm odalarda, üst duvarların süslü ahşap panelleri, dokumacıların mekiklerini veya ilmeklerini andıran geometrik düzenlemeler, sekizgenler, rozetler ve birbirine geçen on iki köşeli yıldızlar yeşil, sarı, kırmızı ve siyaha boyanmıştır (Çiz. 1, Res. 3 ve 4). Binanın ilk inşa veya onarım tarihini gösteren herhangi bir yazı yoktur; ancak 1450 yılında, Karamanoğlu İbrahim Bey'in Mamure kalesini restore ettiği y1l olduğu sanılmaktadır. ${ }^{10}$

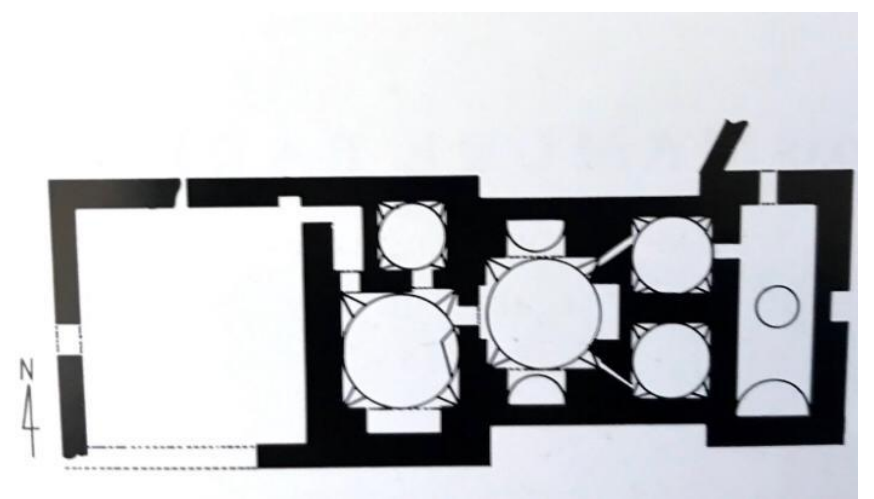

Çiz. 1: Mamure Hamamı Planı (Kaynak: Uysal-Alan 1996, 48)

\footnotetext{
${ }^{7} \mathrm{Bu}$ tarihte yapılan araştırmalar, dönemin Müze Müdürü Arkeolog Sayın Hacı Ali Ekinci tarafından gerçekleştirilmiştir. Bazı bilgi ve fotoğraflar Anamur Müze Müdürlüğü arşivinde yer almaktadır. Bununla ilgili ayrica bkz: Hild-Hellenkemper 1990, 338.

${ }^{8}$ Hild-Hellenkemper 1990,338.

${ }^{9}$ Önge $1970,108$.

${ }^{10}$ Önge 1970, 109.
} 


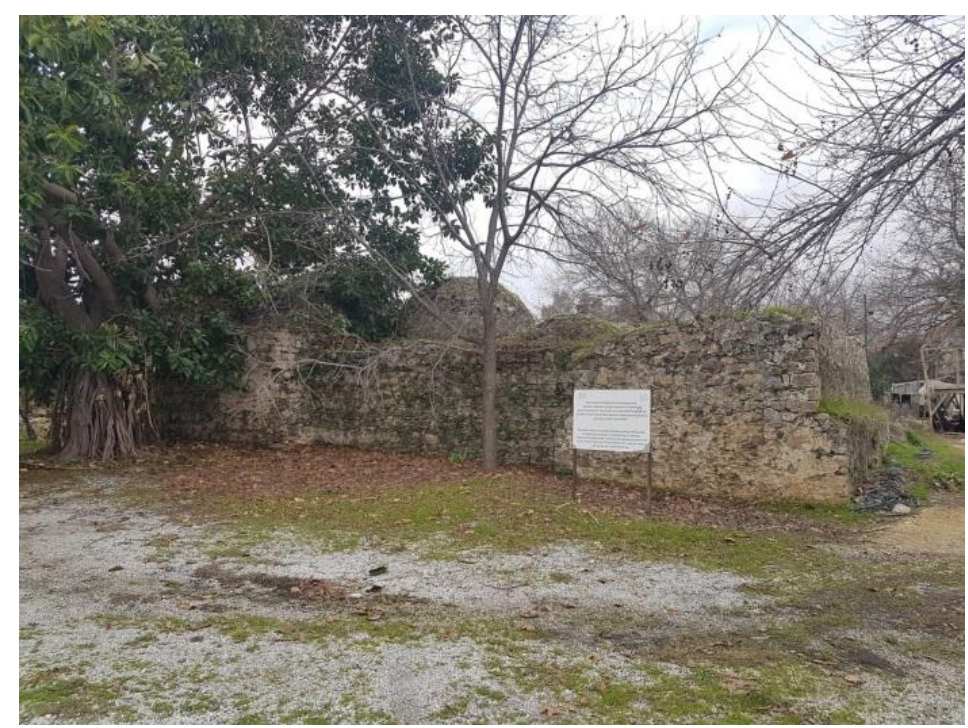

Res. 3: Hamam Görünümü

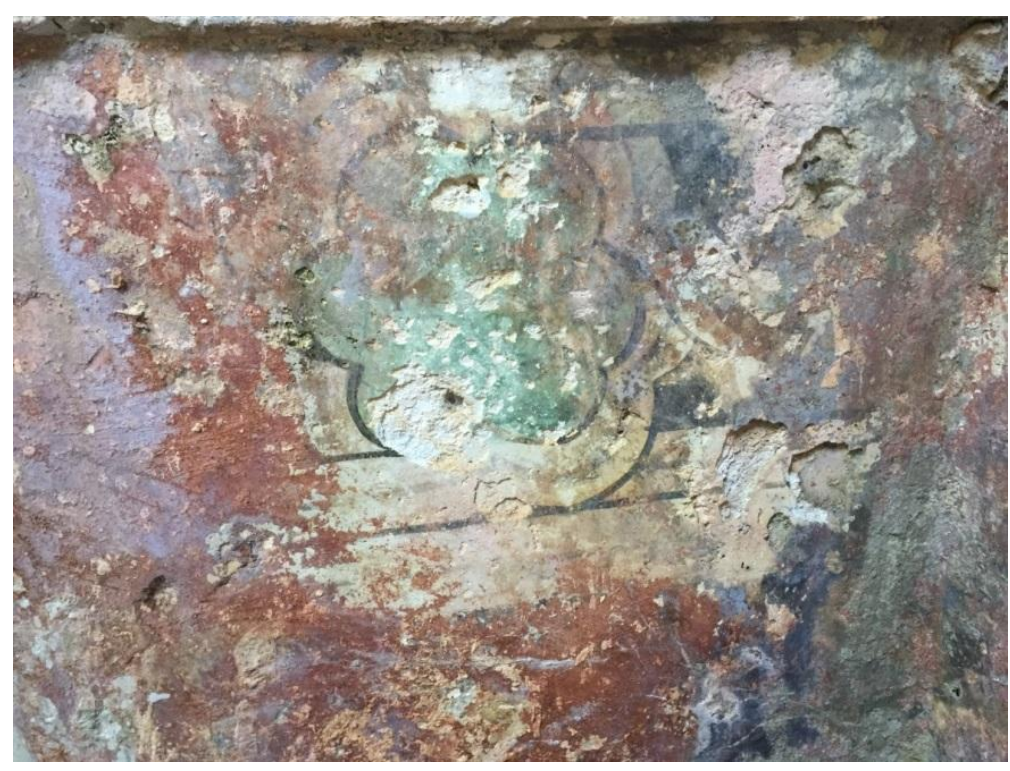

Res. 4: Mamure Hamamı Sıcaklık Bölümünde Yer Alan Kalemişi Süslemelerinden Bir Örnek

Kalenin duvarları, o yörede yaygın olan yapı tekniğine göre kırma taşlarla örülmüştür. $\mathrm{Bu}$ dönemde yapılan çalışmalarda denize bakan tarafta eskiden kalma ve sonra tekrar üzerinde yapılaşmaya gidilmiş temeller bulunmaktadır. Bu bölüm ise 13. / 14. yüzyıllara ait olabilir. ${ }^{11}$ Baş kulenin tasarımındaki dış1 eğimli taban katı, on iki köşeli ikinci kat ve platform Yeniçağ başlarına aittir. ${ }^{12} \mathrm{Bu}$ da bugünkü yapının hemen hemen bütününün, bazı kaynaklarda verildiği gibi Haçlılara değil, Erken Osmanlı Dönemi’ne tarihlenebileceğini göstermektedir. İç kale, Boran'ın çalışmasına göre, MS 3. yy.'da Roma döneminde yapılmış, Alâeddin Keykubad'ın Ermeni ve Haçlılara karşı başlattığı fetihler (MS 1225) sırasında Mübârizüddin Er Tokuş tarafından Anamur Kalesi Anadolu Selçuklu Devleti topraklarına katılmıştır. Karamanoğlu İbrahim Bey Döneminde (MS 1423-1464) tekrar onarım gören kalenin giriş kapısı üzerindeki altı satırlık yazıtta şöyle der:

\footnotetext{
${ }^{11}$ Hild - Hellenkemper 1990, 339.

${ }^{12}$ Hild - Hellenkemper 1990, 339.
} 
"Karamanoğlu Alaeddinoğlu Mehmet oğlu Sultan İbrahim inşa etti. Mamure Beldesi ve kalesi savaş için yardım edilen köşedir. Korunan yerleşim yeri Allah yolunda hediye olarak cihat için onun yardımı ile tamam oldu. Allah'ın nimetlerinden verdiği uyanıklı ve doğru yolu gösterdiğinden şükürler olsun. Bu tarih Mükerrem Şevval ayında 854 yılında yazıldı."13

\section{Mamure Kalesi 2020-2021 Yılı Çalışmaları}

Mamure Kalesi 2020-2021 yılı çalışmaları, Adana Kültür Varlıklarını Koruma Bölge Kurulu Müdürlüğü'nün 18.09.2018 tarih ve 10109 sayılı kararı ile başlamıştır. Bu karara istinaden "Mersin İli Anamur İlçesi Bozdoğan Mahallesi I. Derece Arkeolojik ve Doğal Sit Alanı içerisinde kalan Mamure Kalesi'ne" ilişkin hazırlanan Rölöve, Restitüsyon ve Restorasyon işi konusunda yapılmış olan kazı çalışmaları, Anamur Müze Müdürlüğü denetiminde 04.12.2020 tarihinde başlatılmıştır.

\section{a. C Avlusu Çalışmaları}

Anamur Mamure Kalesi İç Kale Camii ve C Avlusu Restorasyonu ve Kazı Çalışmaları 04.12.2020 tarihinde başlamıştır.

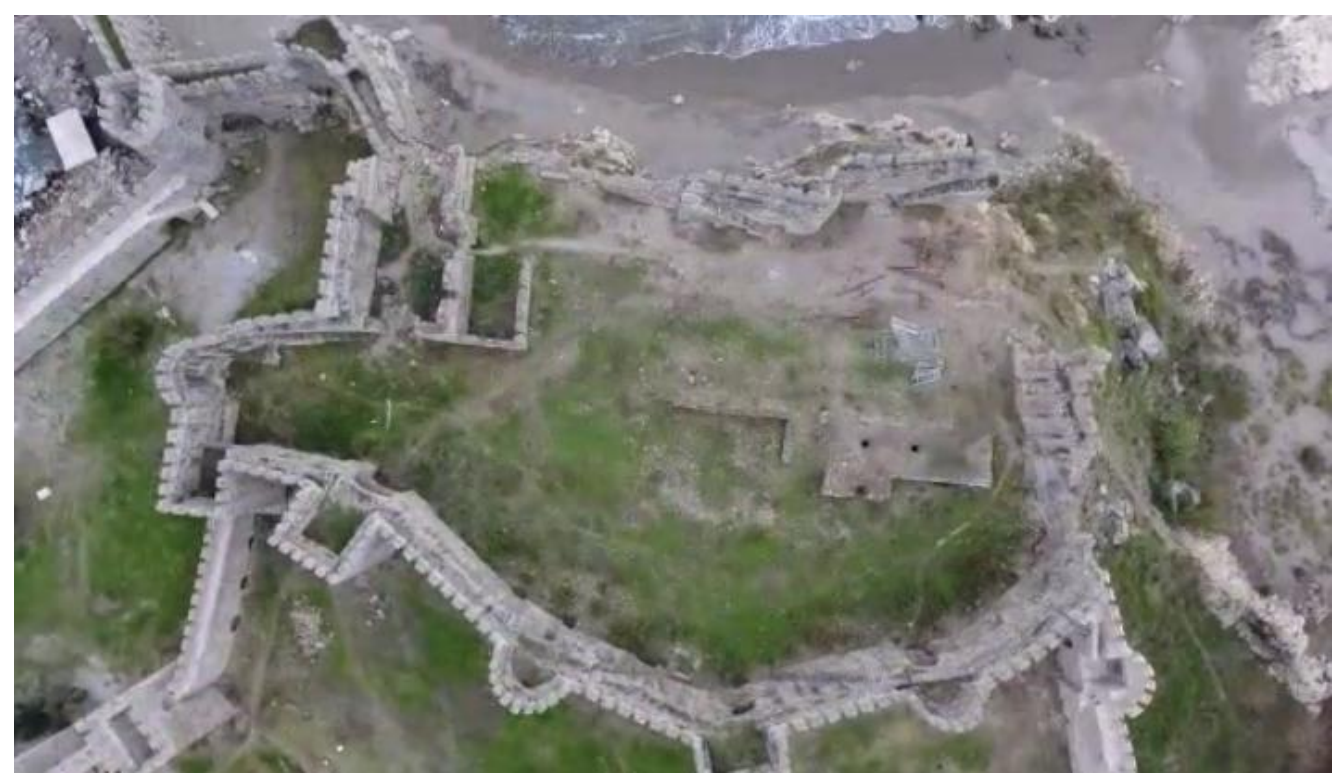

Res. 5: Mamure Kalesi C Avlusu (04.12.2020)

Çalışmalara öncelikle kazı gerektiren alanın belirlenmesi ile başlamıştır. C avlusu kuzey girişinde "KULE C03" olarak adlandırılan kulenin girişi ve zemini baz alınarak güneye doğru çalışılması hedeflenmiştir. Burada çalışma gerçekleştirilmesinin amacı dış kalenin C avlusu ile B avlusunu ayıran duvarın restorasyonu için gerekli düz zemini ortaya çıkartmaktır. Kalenin C avlusunda daha önce hiç çalışma gerçekleştirilmemiştir. Yapılan çalışmalar önce Kule C-03 girişinden başlatılıp daha sonra doğu ve batı yönlerine doğru genişletilerek plan kare anlayışı güdülmeden "açık alan sisteminde" kazı çalışmaları yapılmıştır (Res. 5).

Anamur Müze Müdürlüğü Başkanlığı’nda arkeolojik kazısına başlanan C Avlusunun deniz seviyesinden yüksekliği 15 ile 21 metre aralığında değişmektedir. Bu fark, topoğrafik olarak oluşturulan mekânların ve yapıların alt seviyelerinde yer yer görülmektedir. Alanın güney cephesi ana kayaya oturduğu için buralarda mekân yapısı görülmemiştir. B avlusu ile ortak kullanılan sur duvarı ile ana kayaya oturan sarnıç yapısı arasında mekânlar ve geçişler açığa çıkarılmıştır. Toplamda 22 mekân gün yüzüne çıkarılarak belgelenmiştir.

\footnotetext{
${ }^{13}$ Boran 2004, 216.
} 
Kazı çalışmalarına başlanılmadan önce $\mathrm{C}$ avlusunda görülen mimar yapılar 2 konut yapısı, 2 sarnıç ve 10 kule yapısıdır. Kule C-03'ün karşısında yer alan konutun önündeki moloz yığıntı kaldırılmış ve bu yapıya geçişi sağlayan merdiven ile karşılaşılmıştır. Kule C-03 ile 02 arasında yapılan kazı çalışmalarında 6 mekân açığa çıkarılmıştır. Bu mekânların içinde metal çivi, pipo/lüle, ${ }^{14}$ pişmiş toprak seramik parçaları, dokuma tezgâhı ağırlığı, ağırşak, ${ }^{15}$ değirmen taş1 ve 2. Murat (?) ${ }^{16}$ dönemine tarihlenen 1 adet sikke tespit edilmiştir

Kule C-04, 05-06 ve 07 ile sarnıç yapısının arasında kalan boşlukta da toplamda 12 yeni mekân açığa çıkarılmıştır. Bu mekânlardan da yine Geç Roma, Bizans ve Beylikler dönemine ait sikkeler, 16-18.yy arası olduğunu düşündügümüz testiler (3 adet), seramik parçaları, ${ }^{17}$ öğütme potaları gibi buluntular tespit edilmiştir. Ayrıca kule C-04 ile C05 arasında yassı döşeme taşları, mozaik parçaları gibi buluntular, bu alanın son kot olduğunun göstergesidir. Kule C 03'ün kotunun daha aşağıda olmasının sebebi ise kule girişinin B avlusu ile geçişi sağlamasından dolayıdır.

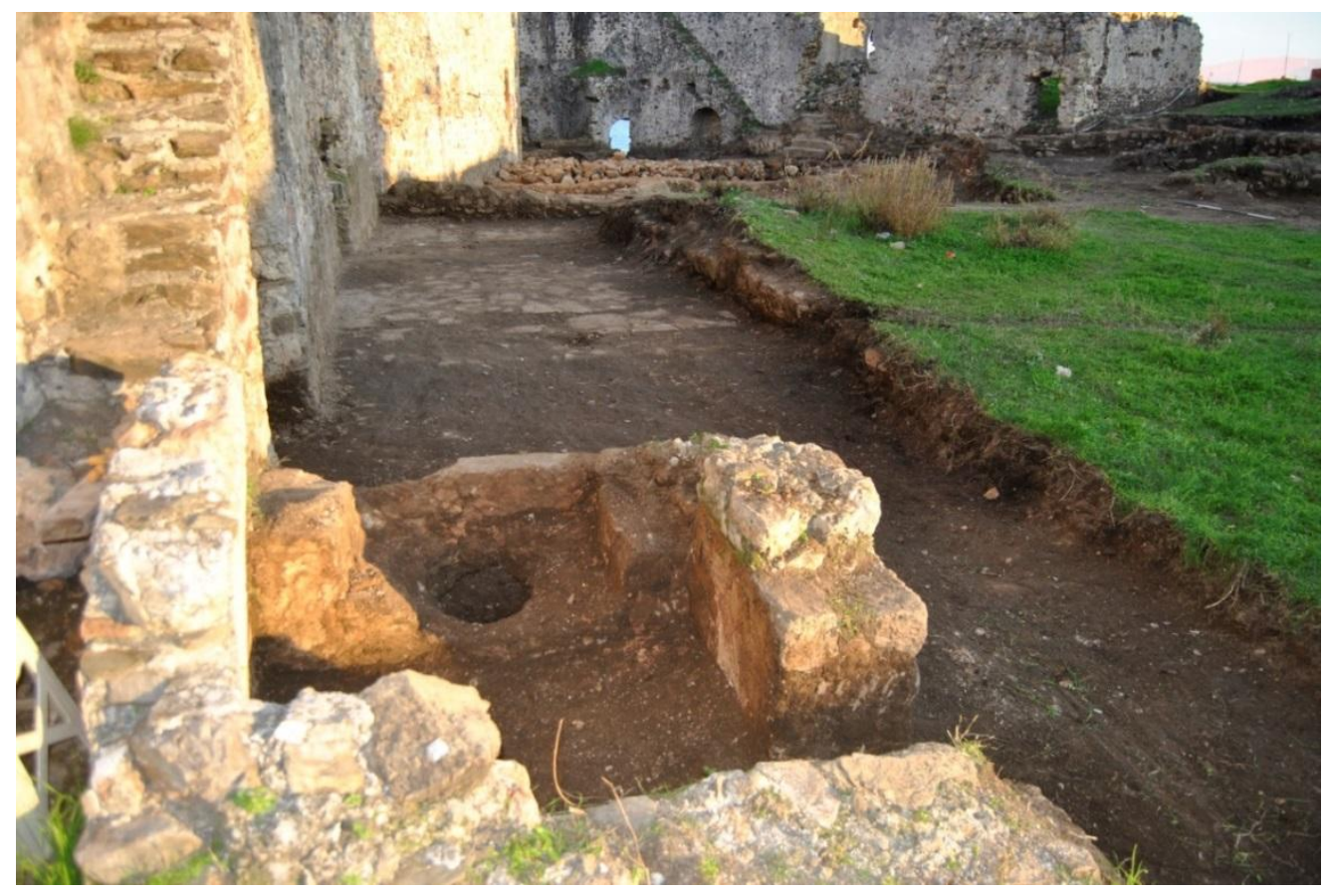

Res. 6: Kule C-04 ile 05 Arasında Tespit Edilen Plaka Taş Döşeli Alan

Sarnıç yapısının etrafında gerçekleştirilen çalışmalar, sarnıç kotu baz alınarak devam ettirilmiştir. Sarnıç kotu ile avlu kotu birbirine çok yakındır. Sarnıcın doğusunda gerçekleştirilen çalışmalarda 1 adet Bizans dönemine ait sikke, ${ }^{18} 1$ adet de muhtemelen dama oyununa ait olan ve üzerinde çizgiler olan pişmiş toprak plaka ve yanında bulduğumuz kemik oyun puludur (Res. 7). Bu plaka ve pul klasik dama ve ya mankala-mangala (?) oyununa aittir ve bu oyun Saka Hunları, Göktürkler Karahanlılar, Selçuklular ve Osmanlılar tarafından oynanan bir oyundur. ${ }^{19}$

\footnotetext{
${ }^{14}$ Pipo/lüle parçalarının benzerleri için ayrıca bkz: Ayhan 2010, ; tipoloji ve katalog için ise yine ayrıca bkz: Budaktaş 2020, 129 .

${ }^{15} \mathrm{Bu}$ ağırşağın benzerleri için ayrıca bkz: Çakmakçı-İnanan 2009, 69.

${ }^{16} \mathrm{Bu}$ sikkenin benzerleri için ayrıca bkz: URL 4 https://www.wildwinds.com/coins/

${ }^{17}$ Tespit edilen testi boyunlarının benzeri için ayrıca bkz: Gök 2017, 148.

${ }^{18} \mathrm{Bu}$ sikkenin benzerleri için ayrıca bkz: URL 5 http://search.freefind.com/find.html?id=8253575\&pageid=r\&mode=ALL\&query=Maurice+Tiberius $+582-602$

${ }^{19}$ Kul 2018, 980.
} 


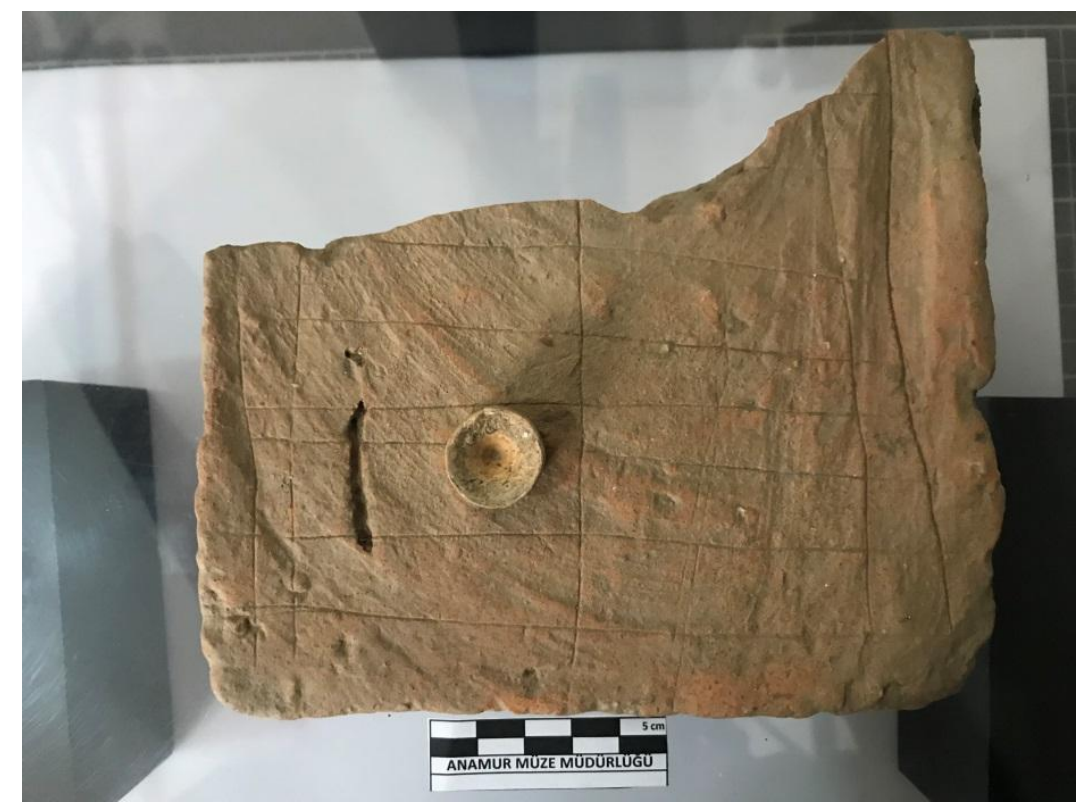

Res. 7: Anamur Mamure Kalesi C Avlusu Sarnıç Yapısı Yanında Tespit Edilen Plaka ve Pul

Sarnıç yapısının doğusunda yer alan ve birbirine çok yakın alanda (Yukarıdaki Bizans örneği ile) tespit edilen diğer bir bronz sikke ise ${ }^{20}$ MS 222-235 tarihlerine denk gelmektedir.

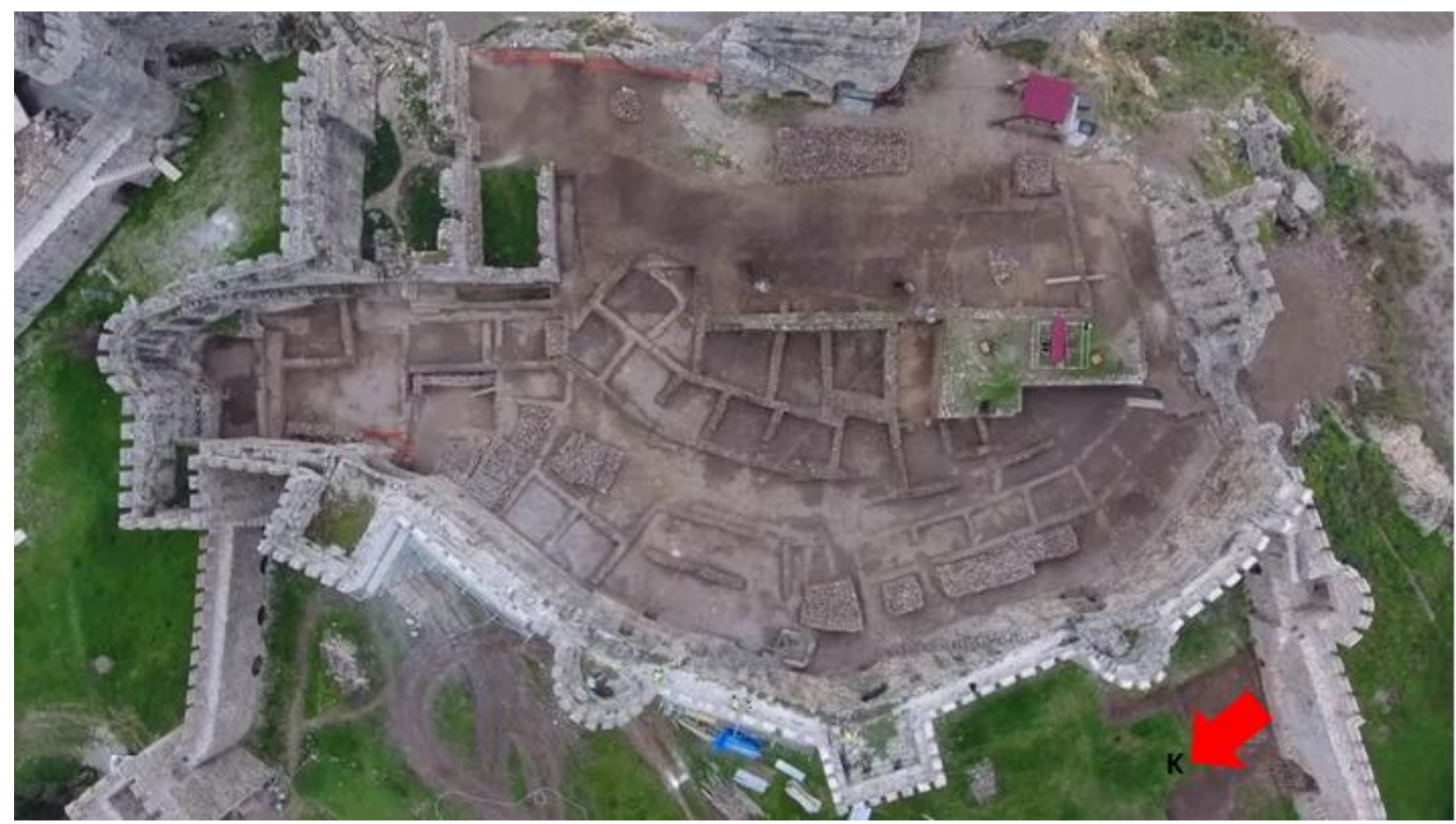

Res. 8: Mamure Kalesi C Avlusunda Tespit Edilen Mekanlar (10.01.2021)

\footnotetext{
${ }^{20} \mathrm{Bu}$ sikkenin benzerleri için ayrica bkz: URL 6.

http://search.freefind.com/find.html?oq=Cilicia+Anemurium+A.D. $+222225 \& i d=8253575 \&$ pageid=r\&_charset UTF8\&bcd=\%C3\%B7\&scs=1\&query=Cilicia + Anemurium + A.D. $+222235 \&$ Find $=$ Search\&mode $=$ ALL \&search $=$ all
} 


\section{b. B Avlusu Çalışmaları}

B avlusu Kazı Çalışmaları, 02.01.2021 tarihinde, magazin olarak adlandırılan, İç Kale Camii'nin batısında yer alan alanda başlamıştır. Bu magazin olarak adlandırılan alan yanyana 11 adettir. Diğer çalışmalar ise avlunun güneybatısında yer alan sarnıç yapısının çevresinde, Magazinler ile sarnıç yapısı arasında kalan boşlukta, Magazinler ile Kule C-02 arasındaki boşlukta, B avlusunun C ile birleştiği alanında duvar kenarlarında yapılan tesviyeler ve caminin harpuşta hizasında çalışmalar yapılmıştır. Kale içerisinde daha önce 1988 yılında Anamur Müze Müdürlügü’nce $B$ avlusunda kurtarma kazıları gerçekleştirilmiş ve daha sonrasında herhangi bir arkeolojik kazı yapılmamıştır

Kule B-07 den başlanıp B-11'e kadar, ardından C Avlusunun B avlusu ile birleştiği ortak sur duvarının hizasında yaklaşık 30-40 cm derinliğinde eski yapılan restorasyonların da alt sınırına inilerek düz bir alan oluşturulmaya çalışılmıştır. Bu düz alan kavramı, sur duvarlarında yer alan barbatanlar (okçu kuleleri) taban seviyesi baz alınarak doğru biçimde yapıyı açığa çıkarmak mottosu ile başlamıştır. Önceki dönemlerde yapılan restorasyon çalışmalarında sur duvarı hizasında hiç kazı yapılmadan duvarların derzleri o anki son seviyede sonlandırılmıştır. 2021 yılında tarafımızca yapılan kazılarda sur duvarının dipleri belirlenen stratejiye göre kazılmış olup barbatan seviyeleri açığa çıkarılmıştır.

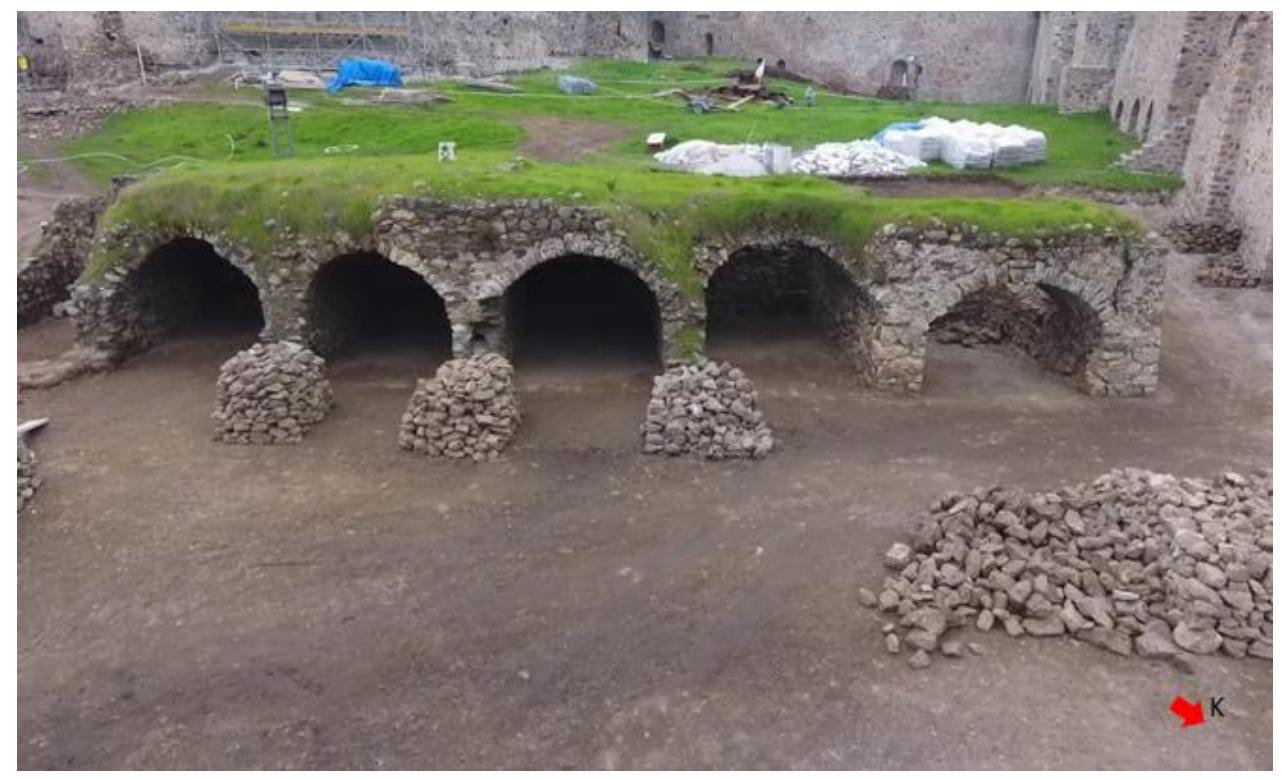

Res. 9: Mamure Kalesi Magazinlerinin Kuzey Doğu Yönünden Görünümü

Magazinlerin önünde ve içlerinde gerçekleştirilen çalışmalar, yapının taban kotunun belirlenmesi için önemlidir. Nitekim yapılan çalışmalar yapının taban kotunun, başlanılan seviyeden $45 \mathrm{~cm}$ aşağıda olduğunu göstermektedir. Bu kanıya magazinlerden 3 ve 4 numaralı olanlarının birleştiği yerde yapılan sondaj ile varılmıştır. 3 ve 4 numaralı tonozun birleştiği yerde 1x1 metre ölçülerinde ve yaklaş1k $90 \mathrm{~cm}$ derinliğinde bir muayene çukuru açılmıştır. Bu bağlamda yapılan çalışmalarda kazıdan sonra, hali hazırda yer alan kotun taban olduğu bunun $10 \mathrm{~cm}$ altında moloz taşlar ile temelinin oluşturulduğu ve ardından alt kısmın tamamen dolgu niteliğinde doldurulduğu görülmüştür. 


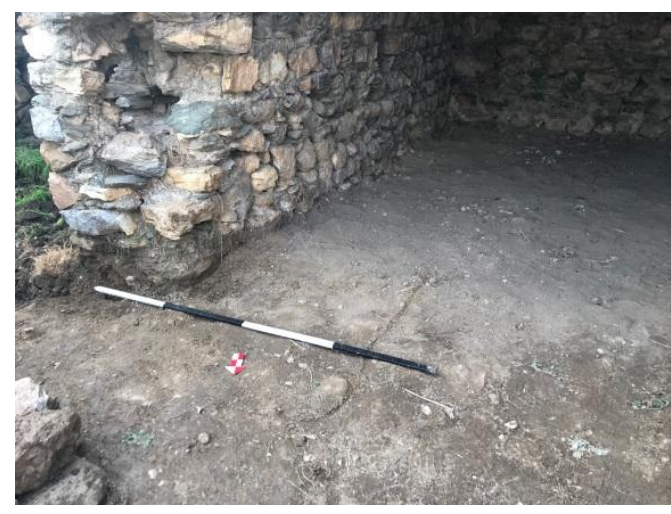

Res. 10: Muayene Çukuru Açılan Alan

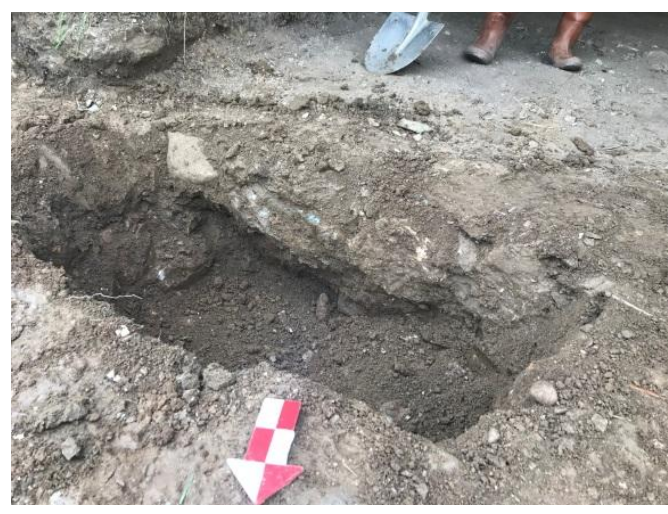

Res. 11: Tespit Edilen Temel ve Dolgulu Toprak

Magazinlerin arkasında gerçekleştirilen çalışmalar, yapının kondisyonu ile ilgili en sağlam verileri sunacak niteliktedir. Burada yapılan çalışmalarda magazinlerin arkasının tamamen moloz taş ve dolgu toprak ile doldurulduğu gözlemlenmiştir. $\mathrm{Bu}$ dolgu hali muhtemelen yapının arka duvarına kadar dağınık biçimde olup, arka duvarı sağlam tutmak için yapılmıştır. 3 ile 4 numaralı magazinin birleştiği noktada doğu-batı doğrultulu magazinleri dik kesecek biçimde oluşturulmuş bir destek hattı açığa çıkarılmıştır. Bu hat magazinleri tam ortadan bölmektedir ve uzunluğu 3 metredir. 11 adet magazinin arkasında gerçekleştirilen çalışmalarda $1-7$ ve 8 numaralı magazin gibi arka duvarın ve üst tonoz örtüsünün de kondisyonunun kötü durumda olduğu gözlemlenmiş̧tir.

Sarnıç yapısı ve etrafinda gerçekleştirilen çalışmalarda toplamda 6 adet mekân tespit edilmiştir. Bu mekânlar, tıpkı $\mathrm{C}$ avlusunda gördüğümüz gibi sur duvarları ile paralel biçimde, basit örgü tekniğinde yapılmıştır. C avlusundaki mekânlardan farklı olarak buradaki mekânlar kare bir görünüm vermektedir. Burada yapılan çalışmalarda mekânların açığa çıkarılan duvarlarının korunması gerekmektedir.

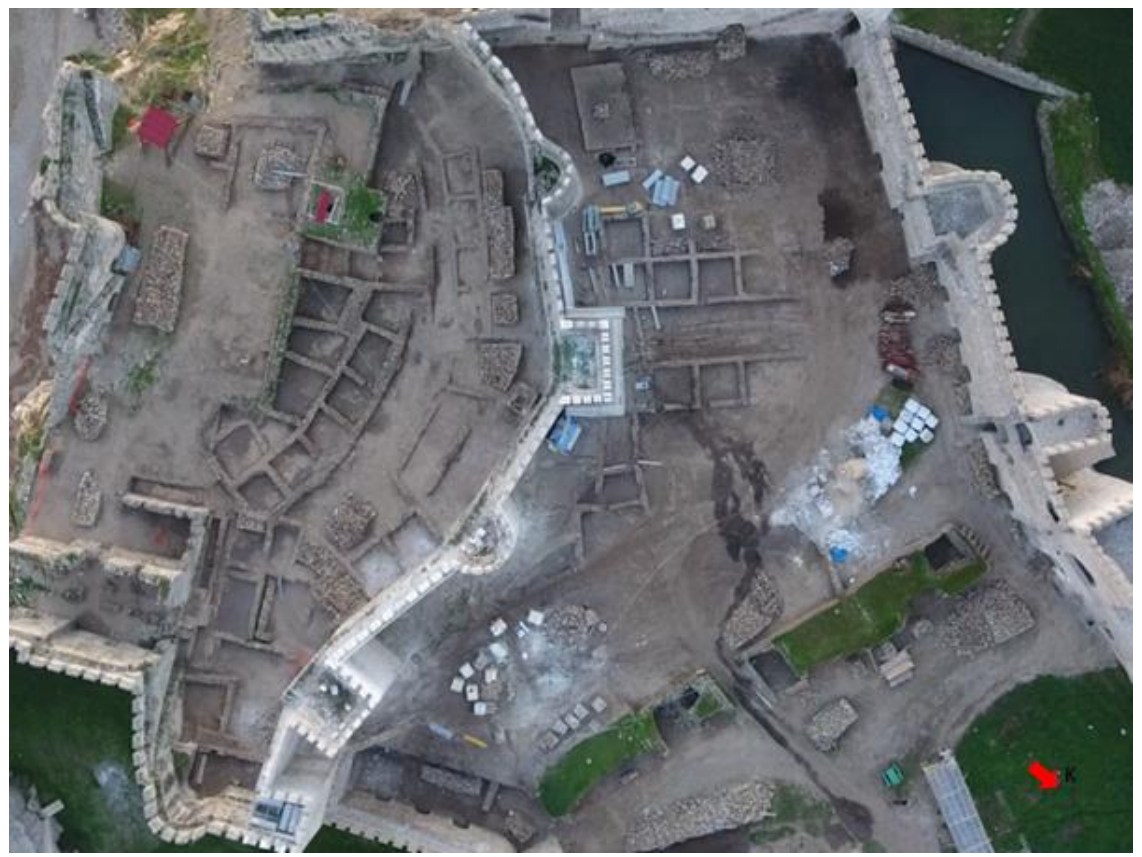

Res. 12: C ve B Avlularını Gösteren Hava Fotoğrafı (28.02.2021) 


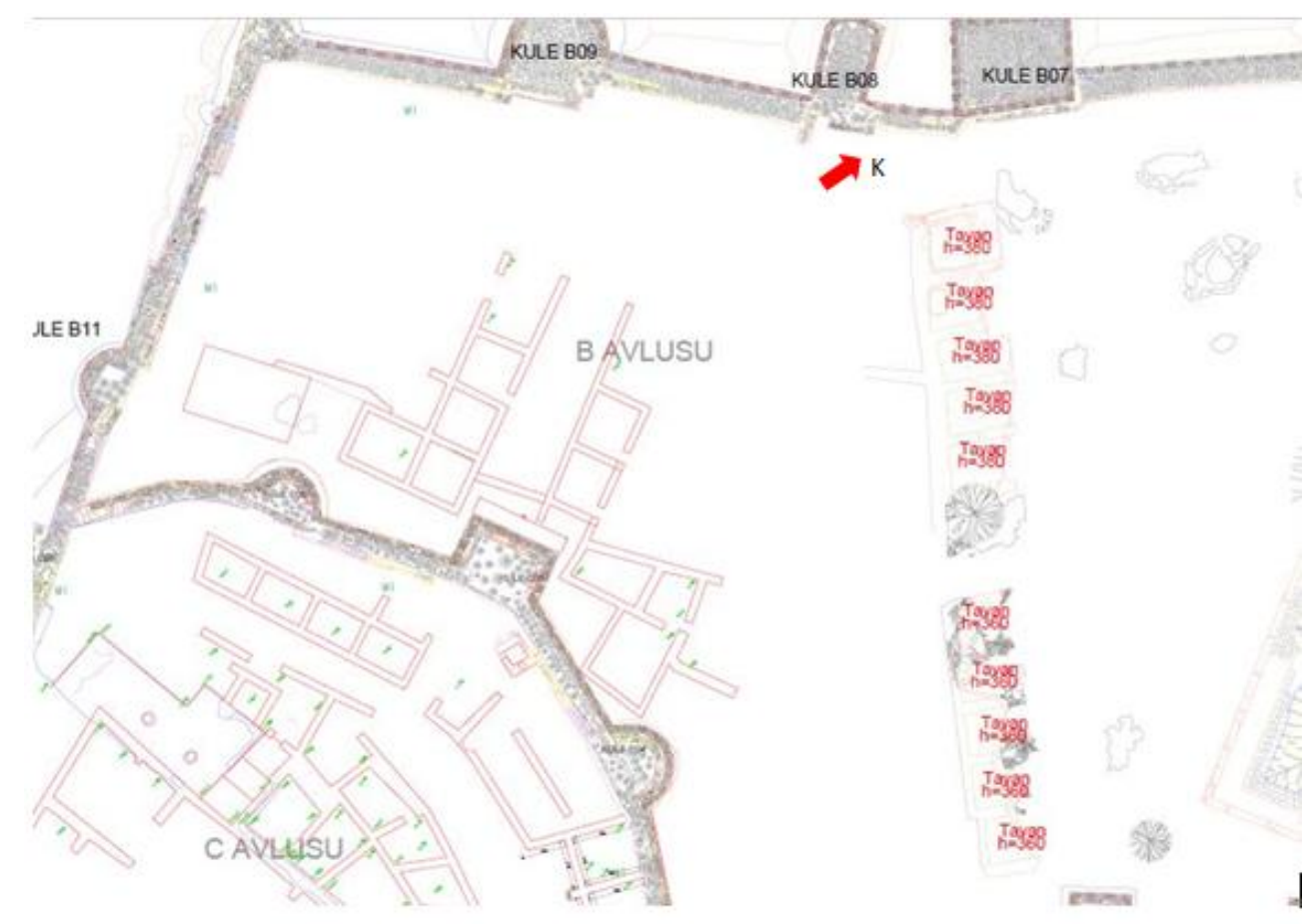

Çiz. 2: C ve B Avluları Mekânlarının Kazı Sonrası Çizimi

\section{Sonuç}

Anadolu'yu yurt edinen Türkler çok sayıda yeni kale inşa ettikleri gibi, stratejik bakımdan önemli olan eski kalelerin de onarımını üstlenmiştir. Ayrıca yeni bölümlerin eklenmesi sonucu eski kaleler birer Türk kalesi haline dönüşmüştür. ${ }^{21}$ Anamur Mamure Kalesi, iç kale ve diş kaleden oluşan yerleşim alanı içindeki kaleler içinde değerlendirilmektedir. Mersin, Akdeniz Bölgesi'nin en güzel ve bünyesinde birçok kaleyi barındıran sahil kentlerinden biridir. Bu özelliği şehrin deniz ticaretinde de ehemmiyetli bir noktaya varmasında etken olmuştur. Mersin'de bulunan kalelerin hemen hepsi Orta Çağ'da inşa edilmiş olup günümüze gelen mimari özellikleri bakımından ağırlıklı olarak Roma ve Bizans dönemi izlerini taşımaktadırlar. Anamur Mamure Kalesi'ni de içinde barındıran Kilikya bölgesi, ${ }^{22}$ savunma yapılarının çokluğu açısından zengin bir coğrafya olup, savunma yapılarının çoğu günümüzde ayakta durmakta ve üzerinde barındırdıkları tarihi süreçleri bugünlere ulaştırmaktadır. Alanya Kalesi ile benzerlik gösteren iç kale tamamıyla Türk devri özelliğini yansıtmaktadır. ${ }^{23}$

2020-2021 yılları arasında Mamure Kalesi'nde yapılan çalışmalarda tespit edilen buluntular, Kale'nin en erken yerleşiminin MS 3 ile 4. yy, en geç ise 18 ile 19. yy arası olduğunu göstermiştir. Bu durum, Kilikia Bölgesi için önemli bir konumda olan Mamure Kalesi'nin kurulduğu zamandan bu yana sürekli bir yerleşim gördüğ̈nü göstermektedir (Res. 25-26).

Hamamda ve kalenin içinde bulunan temel duvarlarının kalıntılarından, hamam ve Mamure kalesinin aynı yerleşimin parçası olduğu sonucuna varabiliriz.

C Avlusunda tespit edilen ve dama oyununa ait olduğu düşünülen plakanın (Res. 7$)^{24}$ benzeri (hamur rengi ve tip olarak aynı olmasa da) 2018 yılında Rusya'nın Finlandiya sınırına yakın

\footnotetext{
${ }^{21}$ Boran 2004, 221.

${ }^{22}$ Kilikya bölgesi kaleleri için ayrıca bkz: Edwards 1987, 22.

${ }^{23}$ Boran 2004, 222.

${ }^{24}$ Bahsedilen benzer örnek için ayrıca bkz: URL 7.
} 
Vyborg Kalesi'nin sprial merdivenlerinin birinin altında 13. yy'a ait bir odanın içerisinde tespit edilmiştir (Res. 21).

Yapılan çalışmalarda tespit edilen sikkelerden birinin en önemli özelliği "Cilicia Anemurium" baskısı olmasıdır. Kaynaklarda belirtildiği üzere Mamure Kalesi, Anemurium Antik Kenti'nin dış koruyucu kalesi olarak kayıtlara geçmektedir. Bu baskıda sikkenin bulunması, Rygmanoi Antik Kenti olarak bilinen Mamure Kalesi alt yerleşiminin varlığı açısından çok önem arz etmektedir (Res. 23).

Tüm bu çalışmalar 1şı̆̆ında Mamure Kalesi C avlusunda 3 farklı evre tespit edilmiştir. Bu evreler Geç Roma- Bizans, Selçuklu- Beylikler ve Osmanlı dönemidir.

B Avlusunda yer alan mekân içlerinde ve sarnıç üzerinde tespit edilen buluntular değerlendirilecek olursa, bu alanın 17-19. yüzyıllar arası yoğun kullanıldığı söylenilebilir. Tespit edilen testiler, at binit takımları ${ }^{25}$ buranın en geç bulutu grubunu oluşturmaktadır (Res. 19). Ayrıca çok net olmamakla birlikte Mekân-3 ve 4 'te tespit edilen yangın hattı, bu alandaki faaliyetlerin bir yangınla son bulduğunu düşündürmektedir. ${ }^{26}$

\section{Mamure Kalesi 2020-2021 Sezonu Buluntuları}

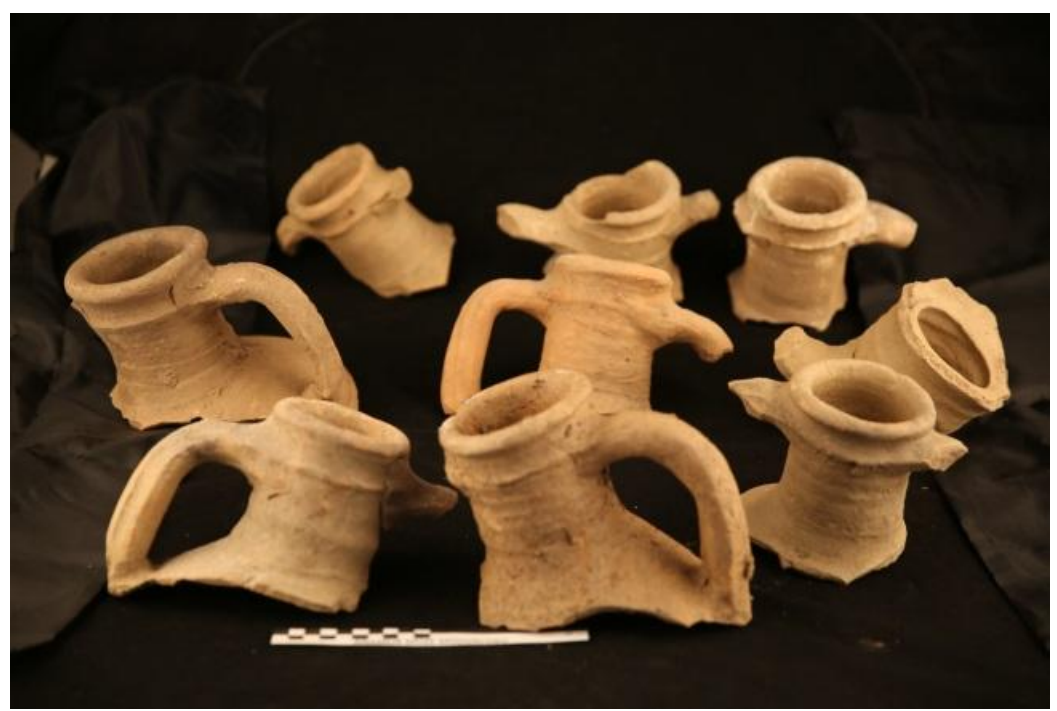

Res. 13: Pişmiş Toprak Seramik Parçaları C Avlusu

\footnotetext{
${ }^{25}$ At Binit Takımlarının benzerleri için ayrıca bkz: Dingeç 2011, 15.

${ }^{26}$ Son Not: Son dönemlerde Mamure Kalesi'nde yapılan restorasyonların ardından çeşitli haber sitelerinde yer alan "Kaleye PVC Pencere Takıldı" şeklinde haberler gerçeği yansıtmamaktadır. Kalenin girişine yakın tarihte inşa edilen bilet satış alanı ve bu alana takılan pencere, sanki kalenin bir yapı elemanıymış gibi aksettirilip toplum yanlış yönlendirilmektedir.
} 


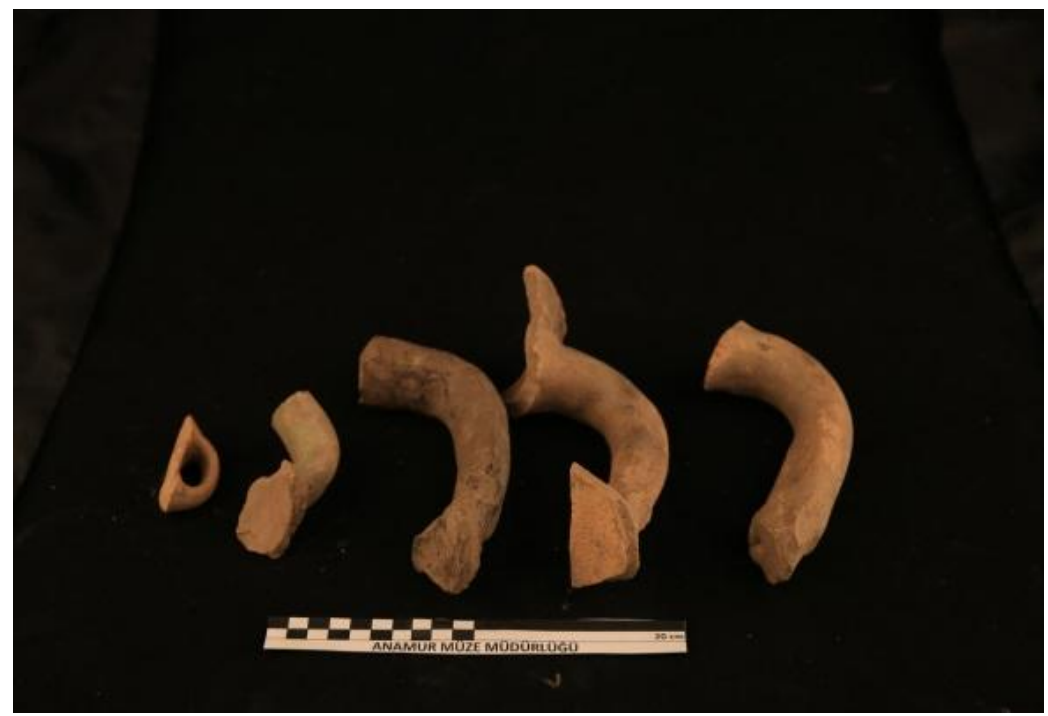

Res. 14: Pişmiş Toprak Seramik Kulp Parçaları C Avlusu

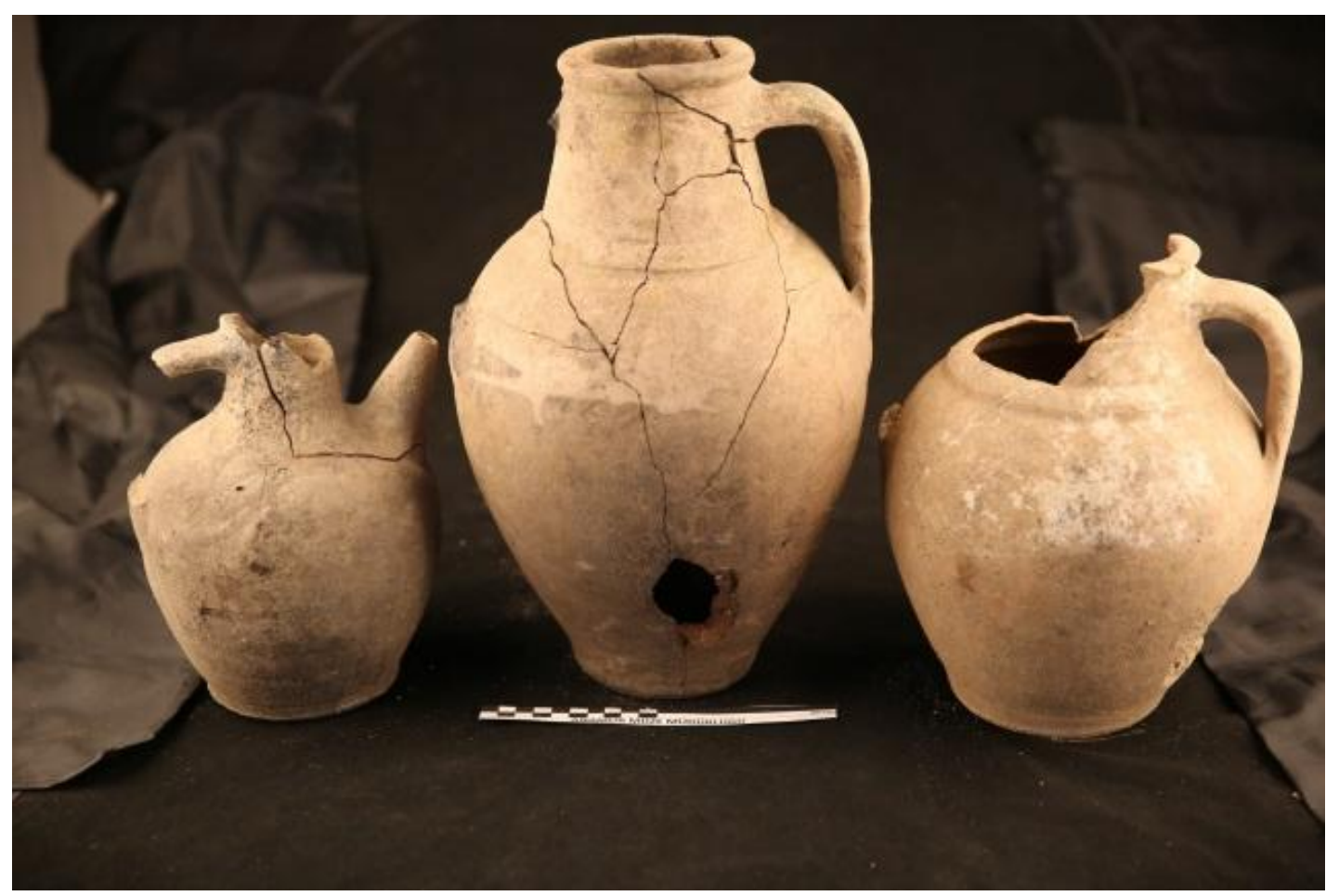

Res. 15: 3 Adet Pişmiş Toprak Testi, C Avlusu, Mekân-11 


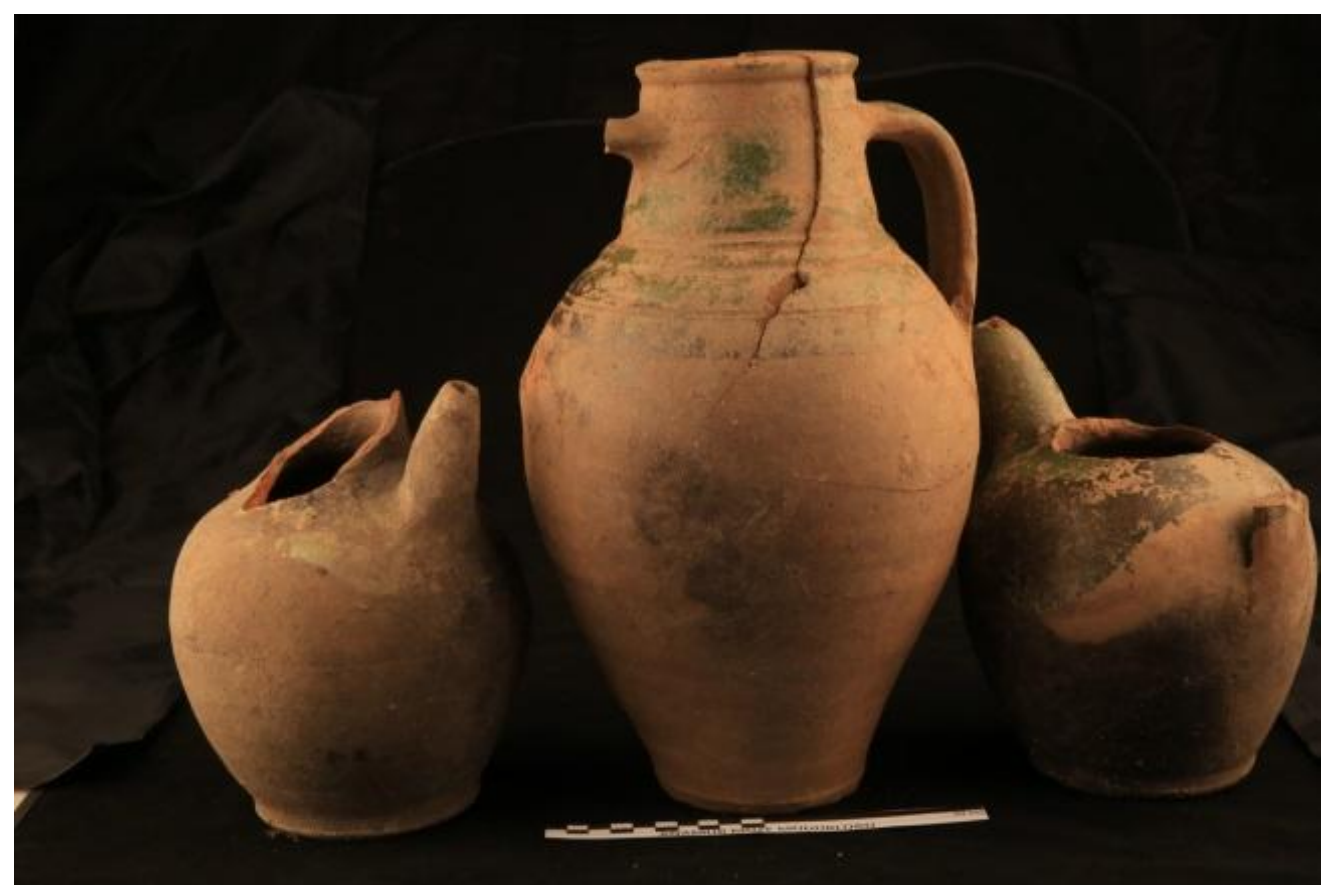

Res. 16: 3 Adet Pişmiş Toprak Testi, B Avlusu, Mekân-2

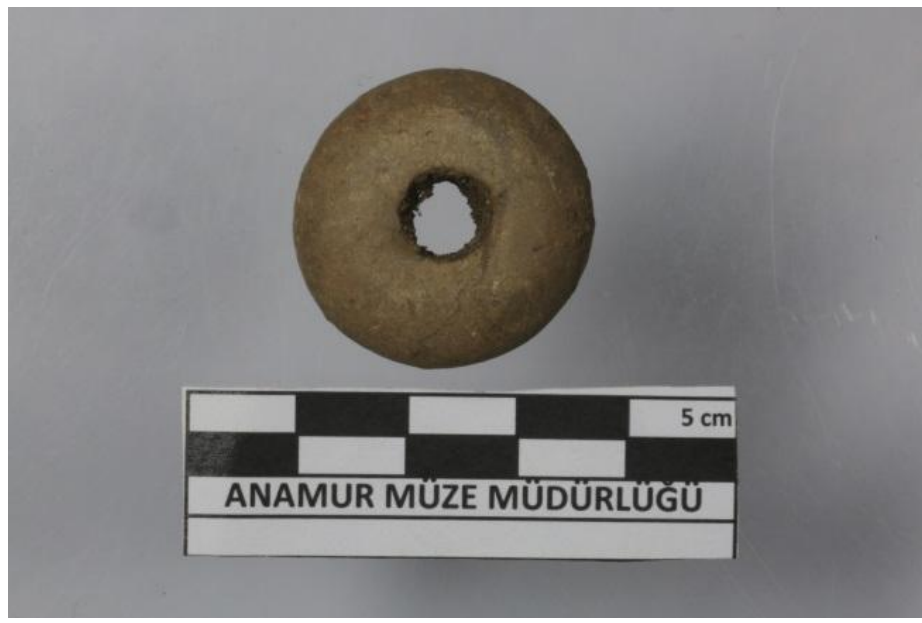

Res. 17: Taş Ağırşak, C Avlusu Mekân-2

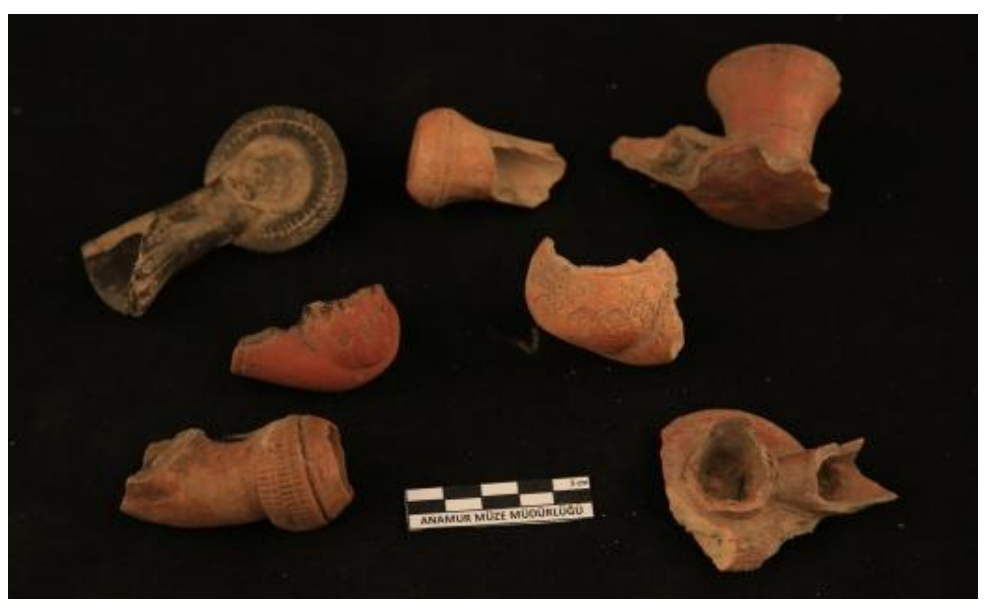

Res. 18: Pişmiş Toprak Lüle/Pipo Parçaları, C ve B Avlusu 


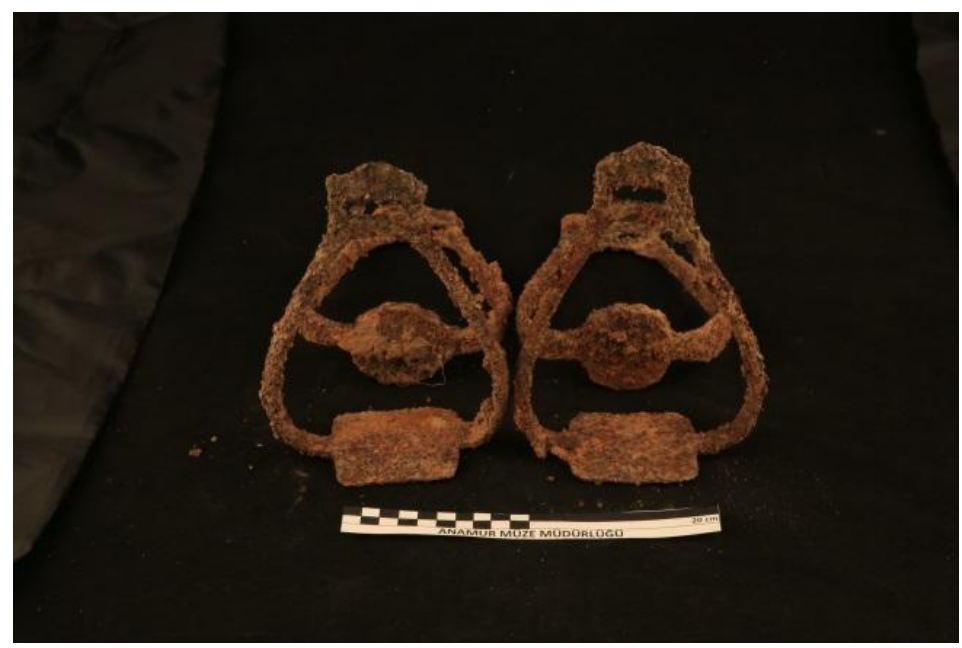

Res. 19: At Binit Takımları, B Avlusu

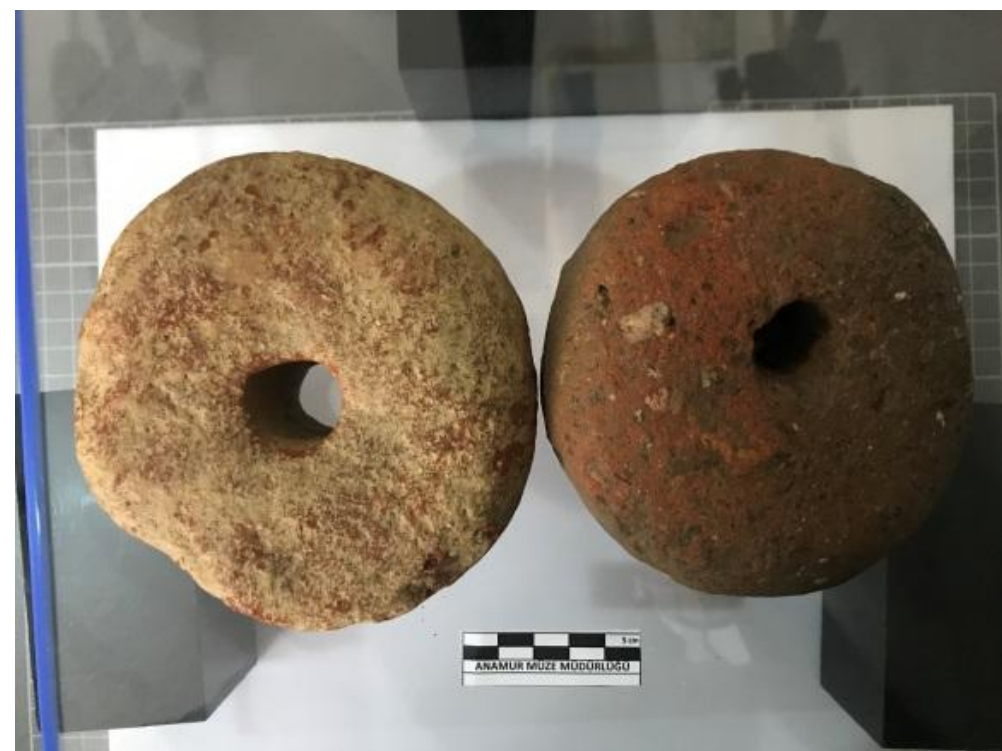

Res. 20: 2 Adet Dokuma Ağırlığı, Pişmiş Toprak, C Avlusu, Mekân-2

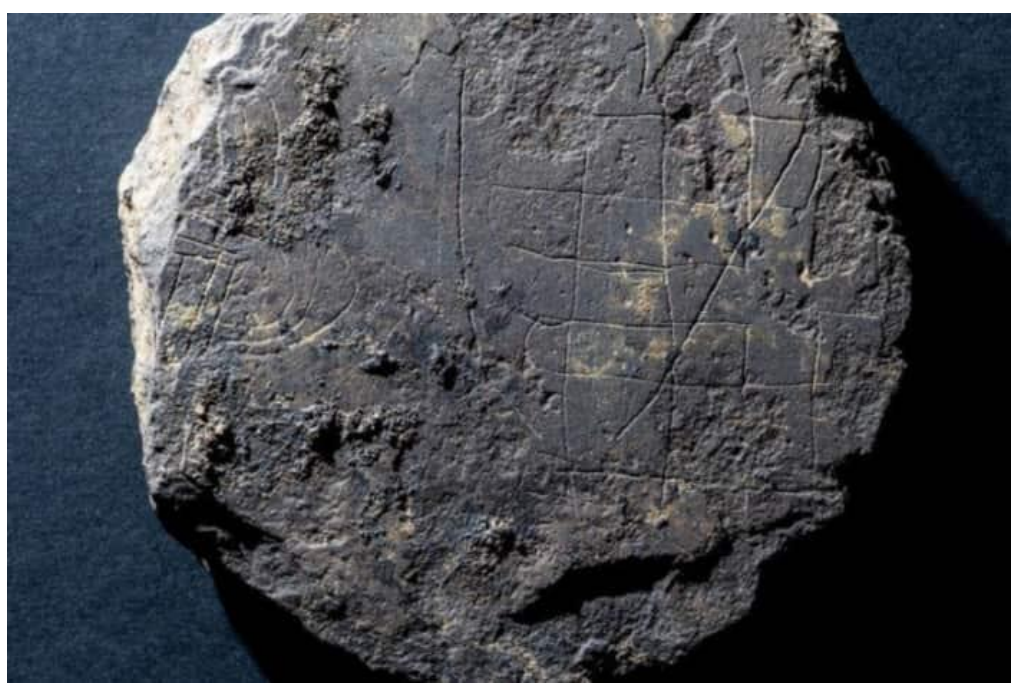

Res. 21: Vyborg Kalesi'nde tespit edilen Orta Çağ Değirmen Oyunu Levhası (Micheal Sharpe/Book of Deer Project) 


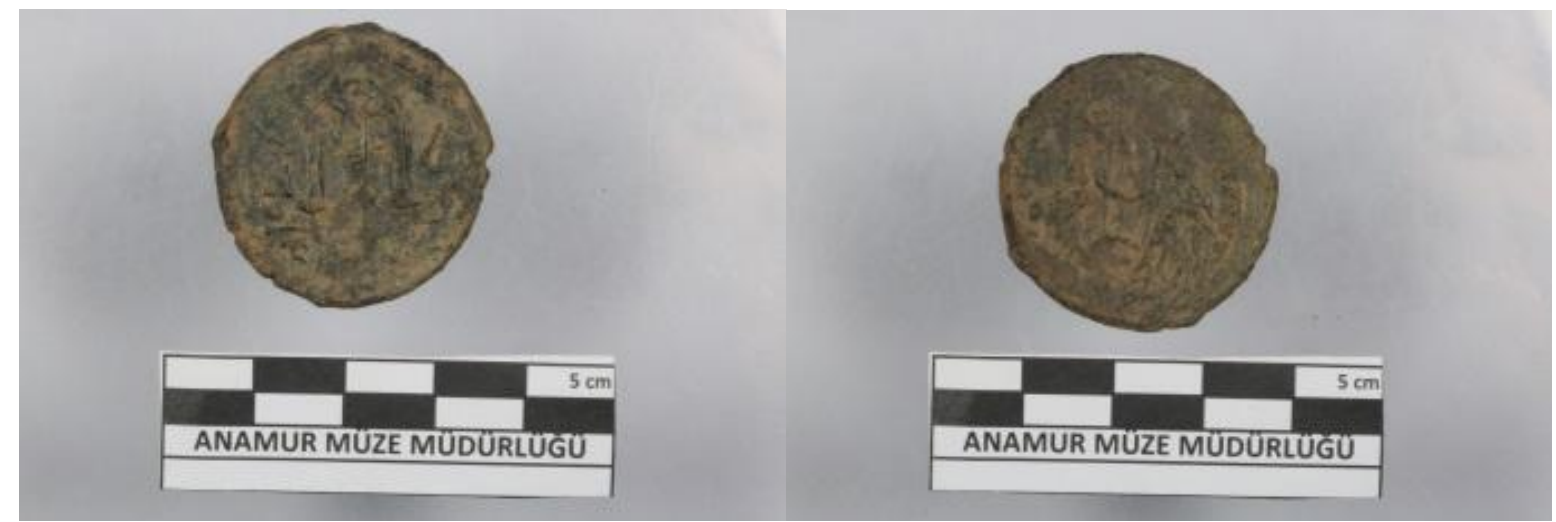

Res. 22: 1 Adet Bronz Sikke, C Avlusu Ön Yüz: Imparator Cepheden, Çelenkli, Drapeli Ve Zirh Giyimli, Să̆ Elinde Asa ve Mappa (Mendil) Sol Elinde Kartal Tutmakta. Arka Yüz: Ortada Büyük M Harfi ( Değer Birimi: 40 Nummi) Solda ANNO, Să̆da Basım Yılı (4),Üstte Haç Monogramı Kesimde THEUP Darphane Yeri (Antiochia)- Maurice Tiberius MS 582602
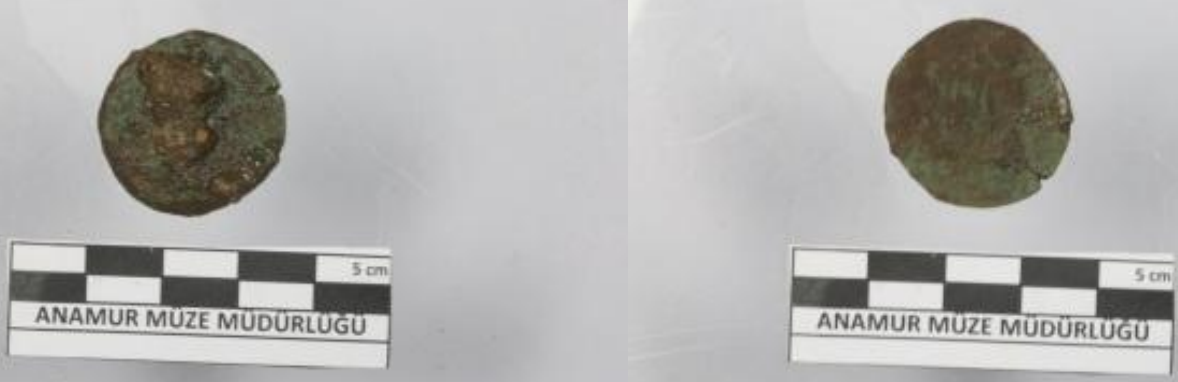

Res. 23: 1 Adet Bronz Sikke, C Avlusu Mekan-15 Ön Yüz: Çelenkli, Drapeli ve Zırh Giyimli Büst Să̆a Dönük Biçimdedir. Arka Yüz: Ortada Dıonysos Çıplak Biçimde Ayakta, Sol Elinde Kantharos, Ayaklarının Önünde Panter Durmaktadır. ANEMOYREION (E-A) Darphane Yeri (Cilicia Anemurium)- Severus Alexander MS 222-235

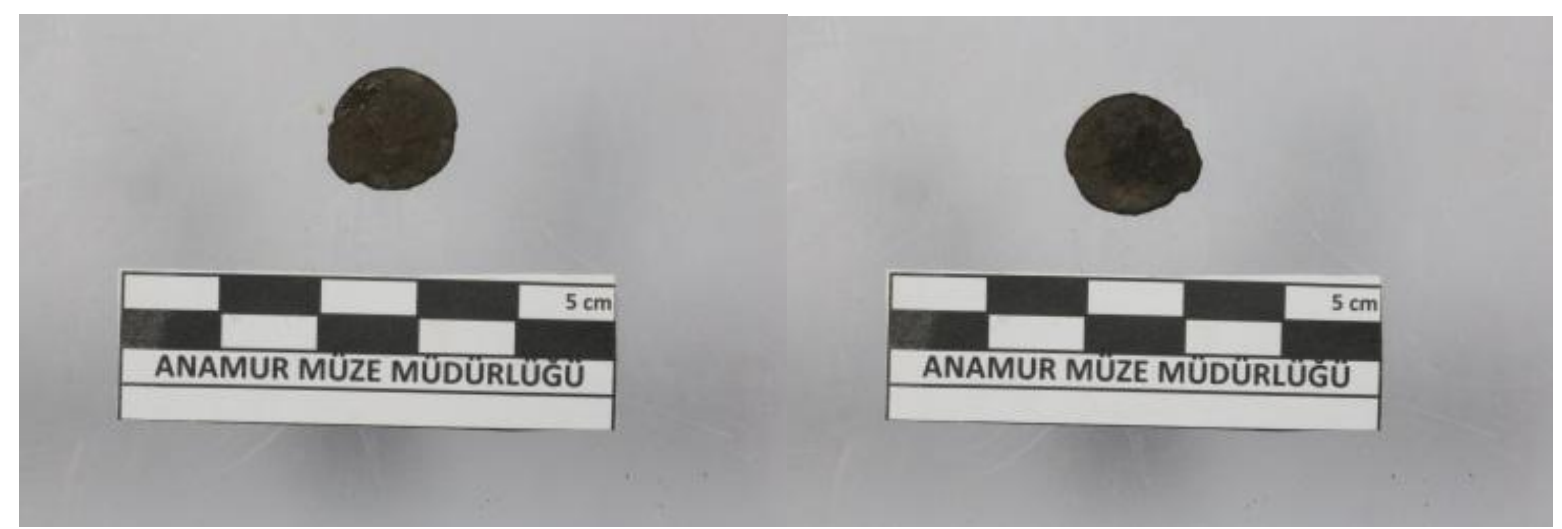

Res. 24: 1 Adet Bronz Sikke, C Avlusu, Kule C-06 Önü Ön Yüz: İnci Diademli, Miğferli Büst Cepheden, Elinde Mızrak ve Kalkan. Arka Yüz: Constantınapolis Oturur Biçimde, Cepheden, Elinde Victoria, Baş Să̆a Dönük. CONCORDIA AVGG Darphane Yeri (Nicomedia)Arcadius (MS 401-403) 


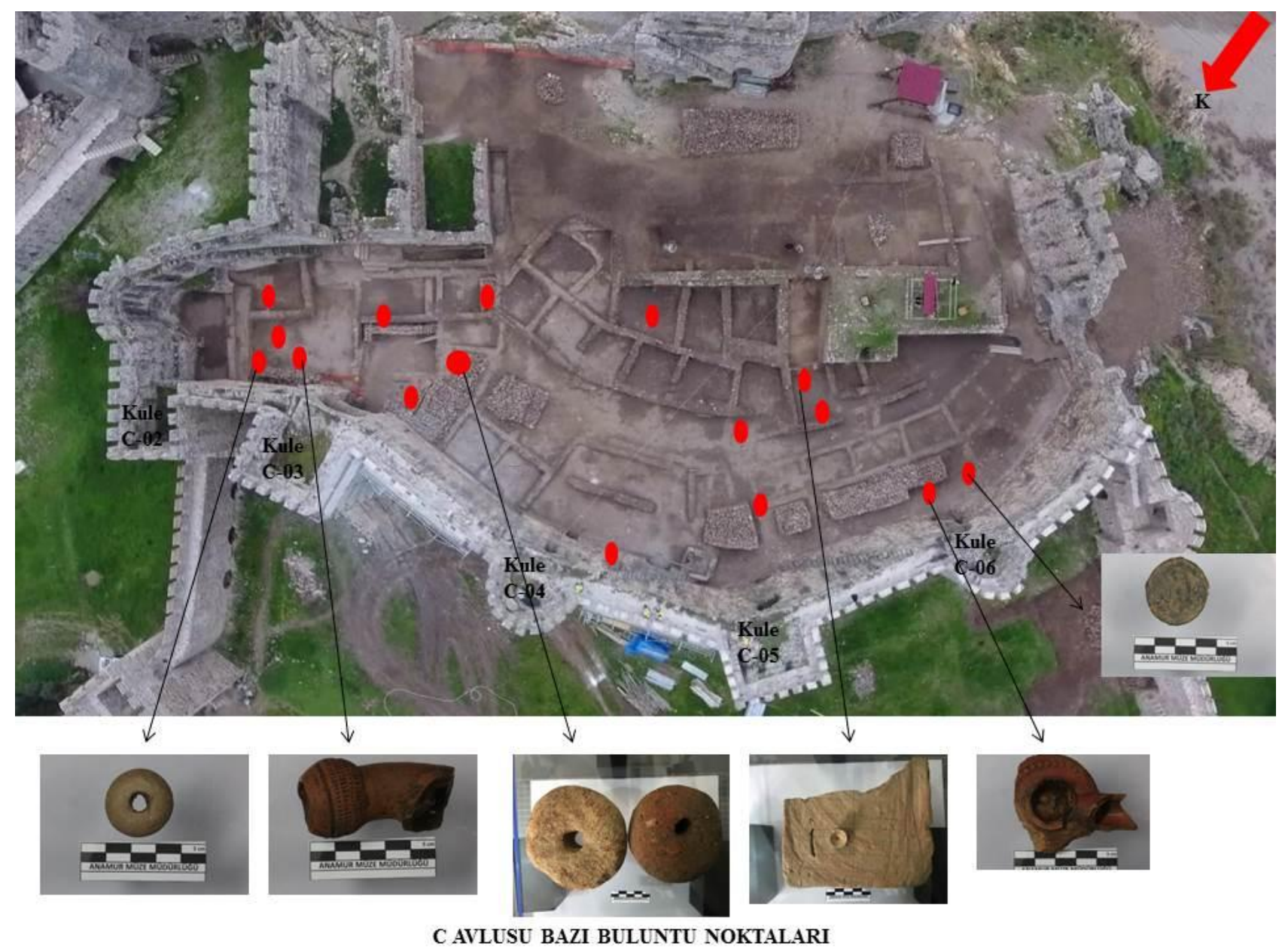

Res. 25: C Avlusunda Tespit Edilen Buluntuların Noktaları

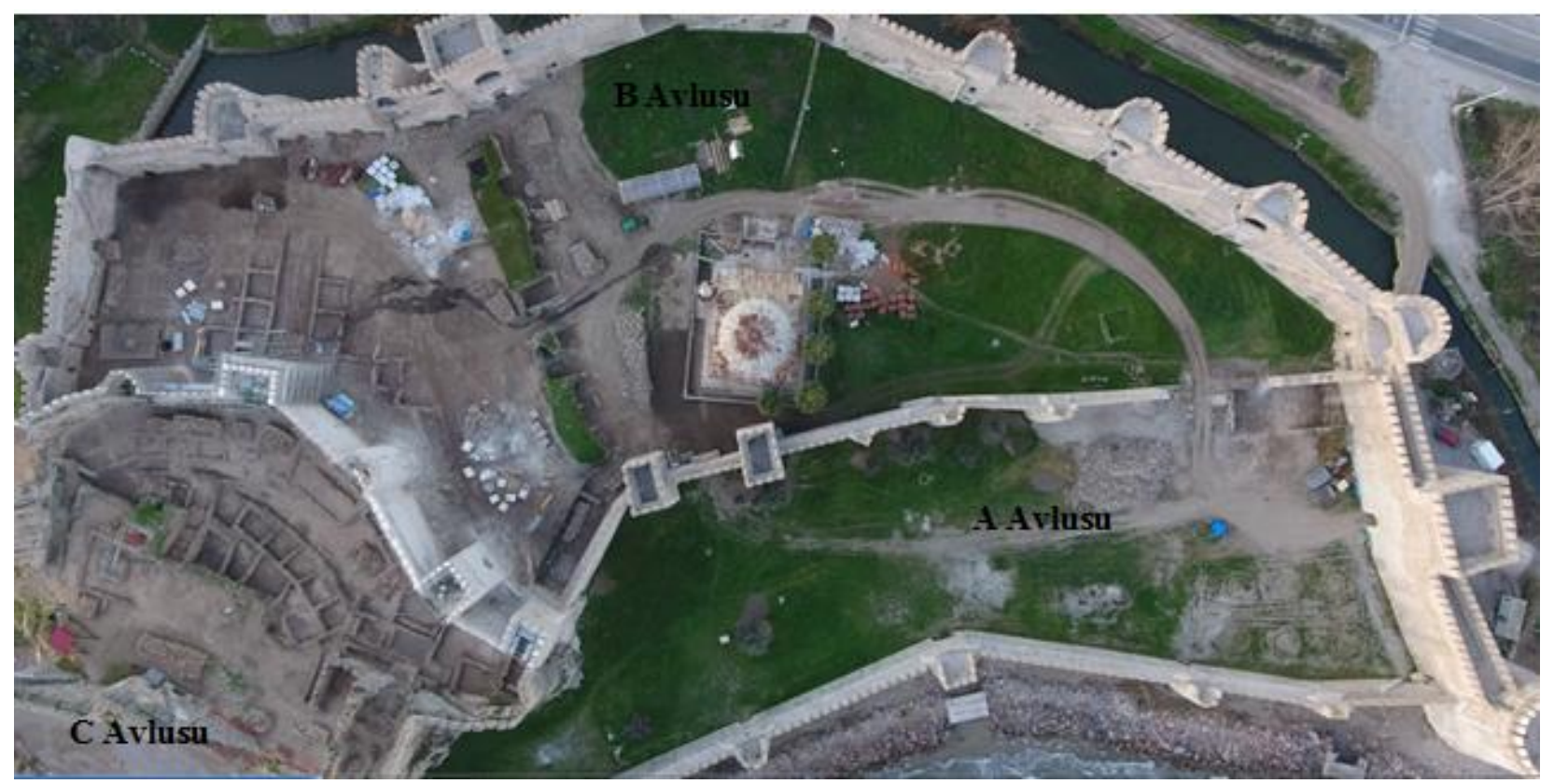

Res. 26: Yapılan Çalışmalar Sonrası Mamure Kalesi Kazı Alanları 


\section{Kaynakça}

Ayhan, G. 2010, "Hasankeyf Kazısı Lüle Buluntularının Değerlendirilmesi”, Sanat Tarihi Dergisi, 19/1, 1-22.

Boran, A. 2004, “Anamur (Mamuriye) Kalesi, Kale Kitabesi ve İç Kale Camii”, Vakıflar Dergisi, XXVIII, 211-224.

Budaktaş, Y. 2020, Divriği Kalesi Kazısı Lüle Buluntuları (2006-2017), Sivas Cumhuriyet Üniversitesi Sosyal Bilimler Enstitüsü, Sanat Tarihi Anabilim Dalı (Yayımlanmamış Yüksek Lisans Tezi), Sivas.

Çakmakçı Z.-İnanan, F. 2009, “Ortaçağ Bizans Günlük Yaşamı ve Üretim Faaliyetleri Açısından Kuşadası Kadıkalesi Buluntularının Ön Değerlendirilmesi”, Sanat Tarihi Dergisi 18/1, 51-72.

Dingeç, E. 2011, “18.Yüzyılın İkinci Yarısında Saray Atlarının Binit Takımları”, Uludă̆ Üniversitesi Fen-Edebiyat Fakültesi Sosyal Bilimler Dergisi, 12/20, 1-20.

Erdoğan, M. 1968, "Osmanlı Devletinde Anadolu Camilerinde Restorasyon Faaliyetleri", Vakıflar Dergisi, VII,149-205.

Edwars, W. 1987, The Fortifications of Armenian Cilicia, Washington.

Gök, S. 2017, Smyrna/İzmir Kazı ve Araştırmaları-II, B. Yolaçan- G. Şakar- A. Ersoy (eds.), Osmanlı ve Avrupa Seramikleri Üzerinden Bir Okuma: Smyrna (İzmir) Agorasindaki Osmanlı Yerleşiminden Mutfak Kapları ile Günlük Yaşam Objeleri, İzmir, 117-150.

Hild, F.-Hellenkemper, H. 1990, Tabula Imperii Byzantini 5 Kilikien und Isaurien, Wien.

Karamanoğlu, O. K. 2012, Anamur'da Dinlence, İstanbul.

Kul, M. 2018, “Türk'ün Strateji ve Zekâ Oyunu Mangala”, Electronic Turkish Studies, 13/18, 979-991.

Önge, Y. 1970, “Anamur Mamuriye Kalesi Yanındaki Hamam”, Vakıflar Bülteni-I, 106-114.

Uysal V.-Alan K. 1996, Anemurium \& The Mamure Fortress, Antalya.

\section{İnternet Kaynakları}

URL 1 https://silo.tips/download/osmanli-dnem-kale-mmars\#modals

URL 2 https://www.kulturportali.gov.tr/turkiye/mersin/gezilecekyer/mamure-kalesi

URL 3 http://www.reiseinfo-tuerkei.de/Tuerkei/Mamure_Kalesi.htm

URL 4 https://www.wildwinds.com/coins/

URL5http://search.freefind.com/find.html $\mathrm{id}=8253575 \&$ pageid=r\&mode=ALL\&query=Maur ice+Tiberius+582-602

URL6http://search.freefind.com/find.html?oq=Cilicia+Anemurium+A.D. $+222225 \&$ id=82535 75\&pageid=r\&_charset $=$ UTF8\&bcd=\%C3\%B7\&scs=1\&query=Cilicia + Anemurium + A.D. + 22 235\&Find $=$ Search \&mode $=$ ALL\&search $=$ all

URL7 https://www.archaeology.org/news/6768-180705-scotland-medieval-game 